\title{
76. PLANKTONIC FORAMINIFERA FROM LEG 37 OF THE DEEP SEA DRILLING PROJECT
}

\author{
Gregory A. Miles, University of Oregon, Eugene, Oregon
}

\section{INTRODUCTION}

During Leg 37 of the Deep Sea Drilling Project, sediments were recovered from seven holes which were drilled at Sites 332, 333, 334, and 335. The sediments, which contain abundant planktonic foraminifera, are composed of calcareous oozes and chalks from above and below acoustic basement. They range in age from Miocene to Pleistocene.

The holes are located west of the median valley of the Mid-Atlantic Ridge, approximately $300 \mathrm{~km}$ southwest of the Azores (Figure 1).

A total of 243 samples was processed for planktonic foraminifera. The number of samples examined at each hole is shown in Table 1.

Where possible, samples were taken from the cores at $75-\mathrm{cm}$ intervals. The samples were processed by boiling them in water to which a small amount of hydrogen peroxide had been added. Many of the samples, especially some of those from Site 334, are chalky and the foraminifera were extracted only with difficulty. Several of these samples were boiled for 10 to $20 \mathrm{hr}$ in a commercial solution of "Quaternary O." After boiling, all samples were wet sieved with a $62-\mu \mathrm{m}$ mesh sieve.

In some holes foraminifera-bearing chalks and limestone are present as interbeds or small veins in the igneous rocks of the basement. Foraminifera were successfully extracted from chalk interbeds in Holes $332 \mathrm{~A}$ and 332B. The limestones are too highly indurated to allow extraction of foraminifera by conventional means. Numerous specimens can be seen in thin sections made from the limestones, but identification even to genus is difficult.

\section{PLANKTONIC FORAMINIFERAL ZONES}

In this report the standard planktonic foraminiferal zonation proposed by Banner and Blow (1965) and refined and expanded by Blow (1969) has been used. Blow's zonation was constructed for use in low latitudes, and some of the zonal taxa which are used are absent or poorly represented in Leg 37 samples. Blow's zonation may then not be the most practical for Leg 37 samples. The zonal scheme is, however, widely known and used by students of planktonic foraminifera and consequently it has been adopted for this report.

In practice, the tropical Atlantic planktonic foraminiferal zones established for the Pliocene by Berggren (1973; see also Berggren and Amdurer, 1973) were used for this epoch. Once the Berggren "PL" zone had been established for a Pliocene sample, that sample was assigned to the appropriate "N" zone of Blow. The zonal scheme of Blow, in part, and the zonation of Berggren for the Pliocene are shown in Figure 2. The absolute ages and zone boundary positions are from Berggren and van Couvering (1974).

\section{ZONE BOUNDARIES}

Although all epoch boundaries were washed during Leg 37 drilling operations, three different zone boundaries were cored: N20/N21, N16/N17, and N15/N16. In addition, the boundary between Zones N19 and N20 may have been cored at Site 335 . The criteria which were used to establish the zone boundaries are discussed below. Cored intervals and zone boundaries in each core are shown in Figure 3.

\section{Zone N20/N21 Boundary}

This boundary was cored in Holes 332A and 333 and possibly in Hole 332B and Site 335. The boundary is established at the first Pliocene downhole occurrence of Sphaeroidinella seminulina and/or S. subdehiscens. In Holes 332A, 332B, and 333, isolated, possibly contaminant, specimens of these species were found in several samples which are stratigraphically above the established zone boundary. In these cases the zone boundary has been established at the first downhole occurrence of several specimens of the above species.

\section{Zone N19/N20 Boundary}

This boundary is determined by the last evolutionary occurrence of Globorotalia margaritae. Scattered rare specimens of this species occur stratigraphically above the Zone N19/N20 boundaries established for Holes 332A, 332B, 333, and Site 335, and were a source of confusion. These scattered specimens are frequently abraded or discolored and are considered to be reworked contaminants.

At Site 335 the first downhole appearance of in situ Globorotalia margaritae is in a sample $75 \mathrm{~cm}$ beneath the first downhole occurrence of Sphaeroidinella seminulina and $S$. subdehiscens. In this hole it appears that Zone N20 is either absent or represented by only a short interval. If the former case is correct, the Zone N19/N20 boundary was not cored during Leg 37 .

\section{Zone N16/N17 Boundary}

This zone boundary was cored only at Site 334 . According to Blow (1969), it is defined by the first evolutionary appearance of Globorotalia plesiotumida from its evolutionary ancestor, G. merotumida. Unfortunately, this is not a useful criterion for the determination of the boundary in Site 334 samples. A thorough examination of Leg 37 upper Miocene cores yielded neither of these two species. Many foraminifera which resemble $G$. plesiotumida and $G$. merotumida were noted, but in every case these can be demonstrated to 


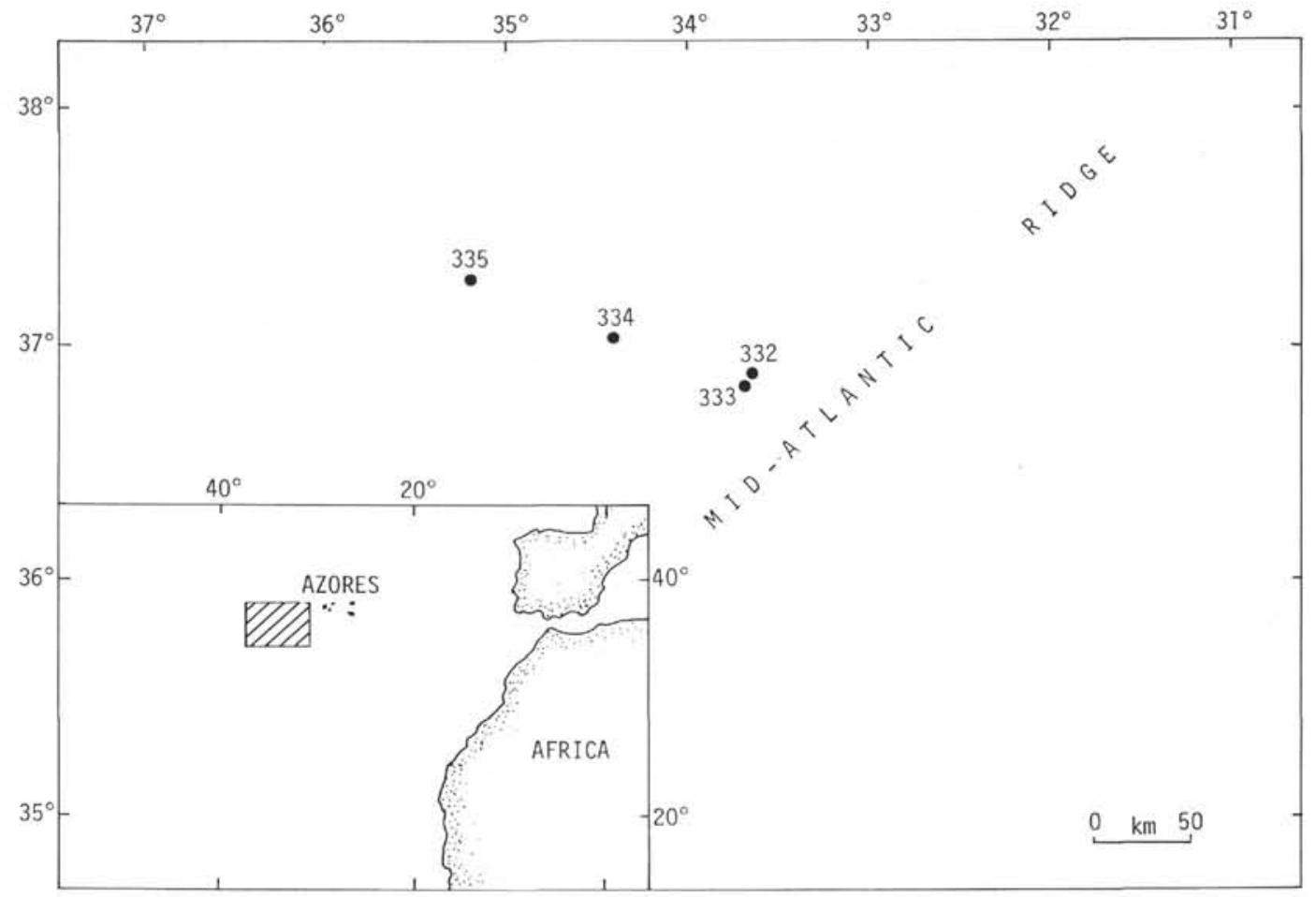

Figure 1. Location of Leg 37 sites.

TABLE 1

Number of Samples

Examined at Each Hole

\begin{tabular}{lc}
\hline Hole & $\begin{array}{c}\text { Number of } \\
\text { Samples Examined }\end{array}$ \\
\hline 332 & 7 \\
$332 \mathrm{~A}$ & 39 \\
$332 \mathrm{~B}$ & 11 \\
333 & 56 \\
$333 \mathrm{~A}$ & 2 \\
334 & 97 \\
335 & 31 \\
\hline
\end{tabular}

be immature specimens of Globorotalia cultrata or $G$. cultrata limbata. Comparisons of these species were made by choosing a specimen which resembles $G$. plesiotumida or $G$. merotumida, then constructing a series of specimens with increasing numbers of chambers. In all cases the final foraminifer in the series is a typical larger specimen of $G$. cultrata or $G$. cultrata limbata.

At Site 334, the Zone N16/N17 boundary is placed between Cores 6 and 7 on the basis of Radiolaria from core-catcher samples. The radiolarian species Ommartartus hughesi makes its first downhole appearance in Sample 334-7, CC and is also present in core-catcher samples from Cores 8,10 , and 11 . The extinction of $O$. hughesi occurs near the top of the Ommartartus antepenultimus Zone (Riedel and Sanfilippo, 1971). The top of this zone is placed just below the top of Zone N16 (Berggren, 1972; Berggren and van Couvering, 1974).

\section{Zone N15/N16 Boundary}

This boundary was cored in the lower part of Site 334. The first in situ downhole occurrence of Globoquadrina advena was used to mark the top of Zone N15.

\section{SPECIMEN PRESERVATION, QUALITY, AND DISTRIBUTION}

\section{Hole 332 (Figure 4)}

Hole 332 consists of a punch core which recovered the uppermost 7 meters of sediment. Planktonic foraminifera of late Pleistocene age are abundant and well preserved. The fauna is dominated by temperate species, and with the exception of Globigerinoides ruber (pink form), characteristic warm water species are rare.

\section{Hole 332A (Figure 5)}

Hole $332 \mathrm{~A}$ was drilled from the base of the punch core (Hole 332) at 7 meters depth to a depth of 333 meters below the sediment-basement contact. One incomplete core containing sediments of Pleistocene age and five incomplete cores containing sediment of late Pliocene age were recovered. In addition, foraminiferabearing chalks were recovered in Cores 13 and 22, which are situated within the basement sequence.

Core 1 is Pleistocene in age and is dominated by foraminifera which are characteristic of temperate regions. However, the presence of Globigerinoides ruber, Globigerinoides sacculifer, Pulleniatina obliquiloculata, and Sphaeroidinella dehiscens is indicative of some warm water influence. Two contaminant specimens of Pliocene age were detected in Core 1 samples. 


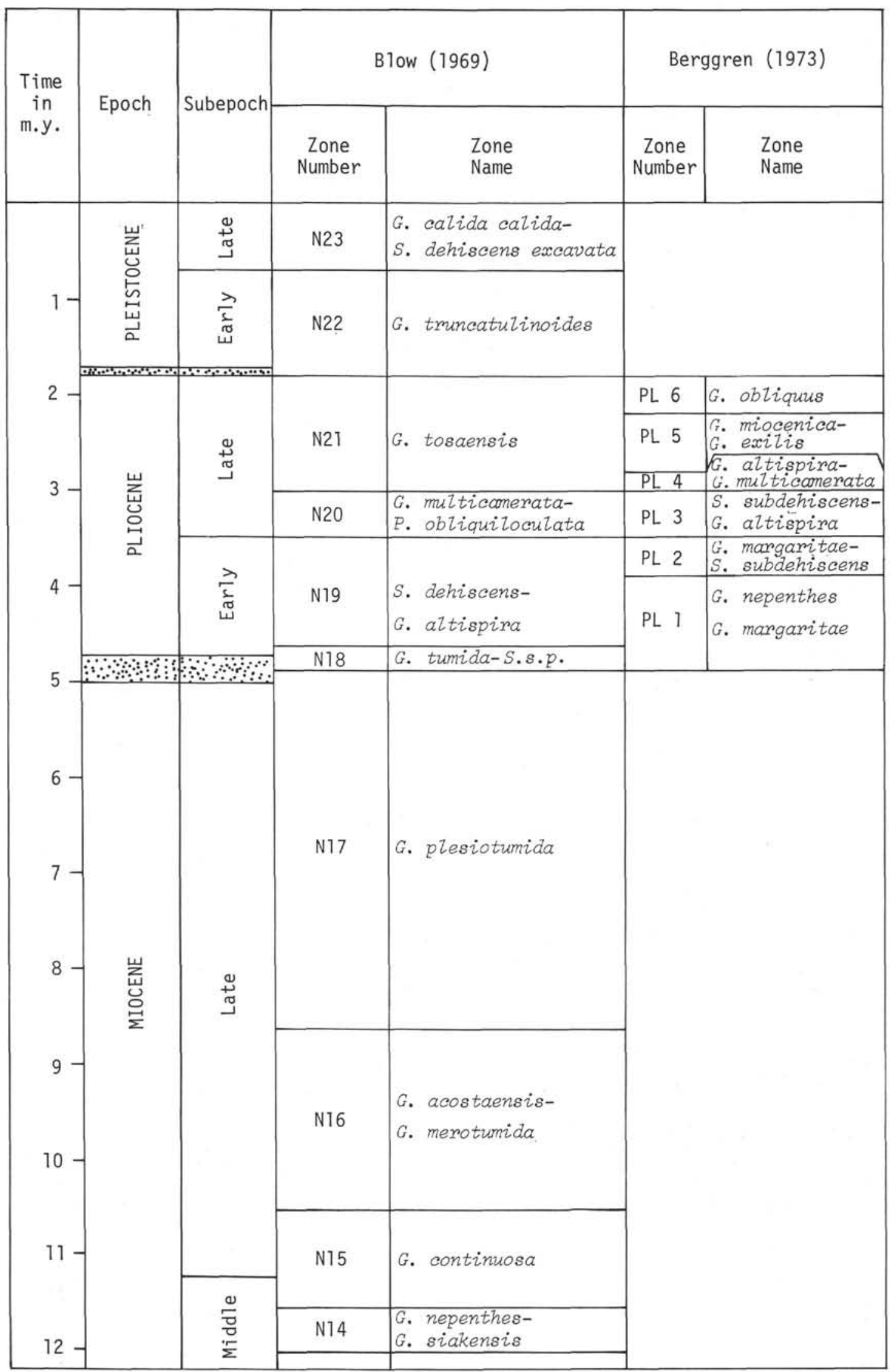

Figure 2. Planktonic foraminiferal zones used in this report. 


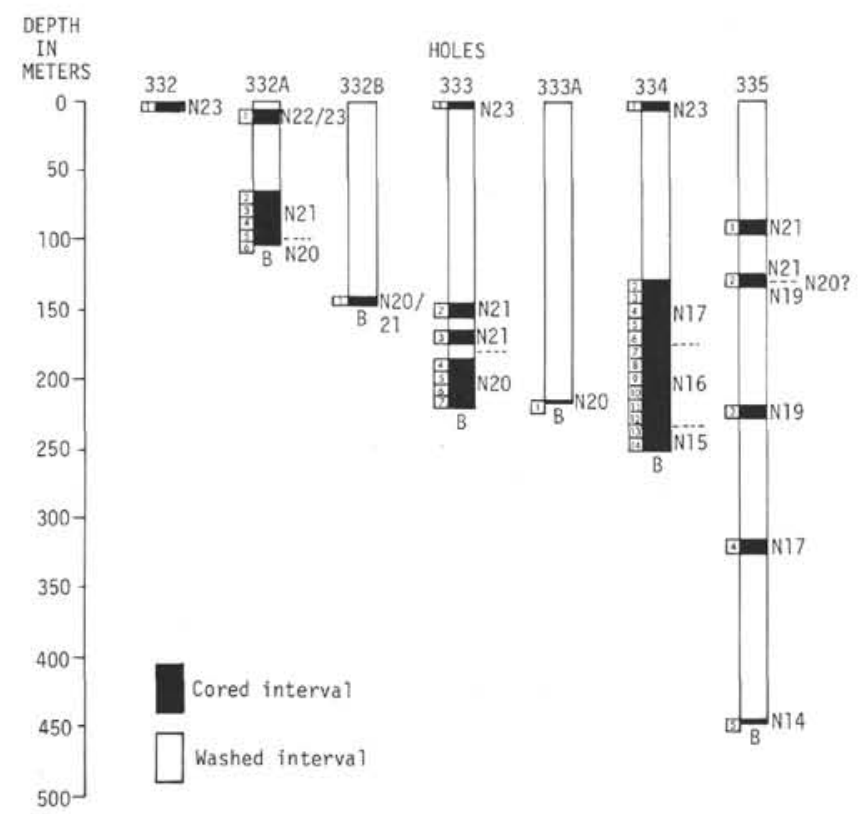

Figure 3. Intervals cored above basement during Leg 37. Zone assignments are given to the right of each cored interval. Core numbers are shown to the left of the intervals. " $B$ " means basement.

Cores 2, 3, 4, and most of Core 5 are within Zone $\mathrm{N} 21$ and are assigned an age of late Pliocene. The most characteristic species of this interval is Globorotalia miocenica, which occurs in many of the samples but is always rare. Three samples in this interval contain single specimens of Globorotalia margaritae, but these are discolored or badly abraded, and are considered to be contaminants. In the interval of $G$. margaritae contamination there are five samples containing one or two specimens each of Sphaeroidinella seminulina or $S$. subdehiscens. These are probably also contaminants.

The Zone N20/N21 boundary, based on the first downhole occurrence of Sphaeroidinella seminulina and/or S. subdehiscens, has been placed in Core 5, Section 6, where several specimens of $S$. subdehiscens are found. Both species become common in Sample 332A$5, \mathrm{CC}$ and remain common in subsequent downhole samples.

The interval containing rare Globorotalia miocenica, scattered single contaminant specimens of Globorotalia margaritae, and scattered rare specimens of Sphaeroidinella seminulina and $S$. subdehiscens is also found in Holes 332B and 333 where there has been some confusion in regard to placement of the Zone $\mathrm{N} 20 / \mathrm{N} 21$ boundary. In Hole 332A, placement of the boundary at the actual first occurrence of $S$. seminulina and/or S. subdehiscens forms a large Zone N20 which requires unusually high average sedimentation rates within the zone, followed by low average sedimentation rates above the zone. Consequently, placement of the boundary within Section 6 of Core 5 in Hole 332A seems justified on the bases of sedimentation rates and the first downhole occurrence of several $S$. subdehiscens.
The absolute age of the sediment-basement contact in Hole $332 \mathrm{~A}$ is placed at 3.0 to 3.3 m.y.

Cores 13 and 22 contain foraminifera bearing chalk which is interbedded with basalt. One sample from Core 13, Section 1, was examined. It is assigned to Zone N20 on the basis of its similarity to Core 6 faunas and because of the lack of diagnostic early Pliocene foraminifera. Two samples were examined from Section 1 of Core 22. Both samples contain a few small specimens of Globigerina nepenthes, and consequently are assigned to that part of Zone N19 below the G. nepenthes extinction datum (i.e., Zone PLl of Berggren, 1973). The absolute age of this interval is 3.7 to $5.0 \mathrm{~m}$.y.

Many samples in Hole 332A were contaminated by Quaternary foraminifera during drilling operations. The contaminants are easily recognized because of their exceptionally good preservation in comparison to the in situ faunas.

\section{Hole 332B (Figure 6)}

One incomplete core of upper Pliocene sediment was recovered immediately above basement in Hole 332B. Nine samples were examined for foraminifera, of which several contain rare Globorotalia miocenica, Sphaeroidinella seminulina, and $S$. subdehiscens. In addition, four samples in this core each contain one or two abraded or discolored specimens of Globorotalia margaritae. The core appears to contain mixed upper Pliocene sediment of Zones N20 and N21 in addition to very minor lower Pliocene contamination. Faunal mixing and the rarity of age-diagnostic foraminifera make exact zone assignment of this core difficult. However, the presence of Globoquadrina altispira and Globorotalia multicamerata in the samples places an upper stratigraphic limit of Berggren Zone PL4 on the sediments in the core, and the absence of in situ Globorotalia margaritae sets a lower limit of Zone PL3. This interval corresponds to Zone N20 and the lowermost part of Zone N21, and has an absolute age of 2.8 to 3.3 m.y.B.P.

Two samples from an interval of chalk which is interbedded with basalt in Section 2 of Core 6 were examined for planktonic foraminifera. The faunas were extracted from the sediment with difficulty and consequently are much smaller than faunas from samples collected above basement. Core 6 is assigned to Zone N20 on the basis of plentiful Sphaeroidinella seminulina and $S$. subdehiscens and on the absence of in situ early Pliocene species.

\section{Hole 333 (Figure 7)}

Hole 333 was drilled on the western slopes of the same valley as Site 332 . In this hole sediments were recovered from a surficial punch core and from a Pliocene section which was cored above basement. The Pliocene section was continuously cored from 145.5 meters subbottom to a depth of 214 meters, with the exception that one core length between Cores 2 and 3 and on core length between Cores 3 and 4 were washed.

Two meters of late Pleistocene sediment were recovered from the punch core (Core 1). The fauna is 


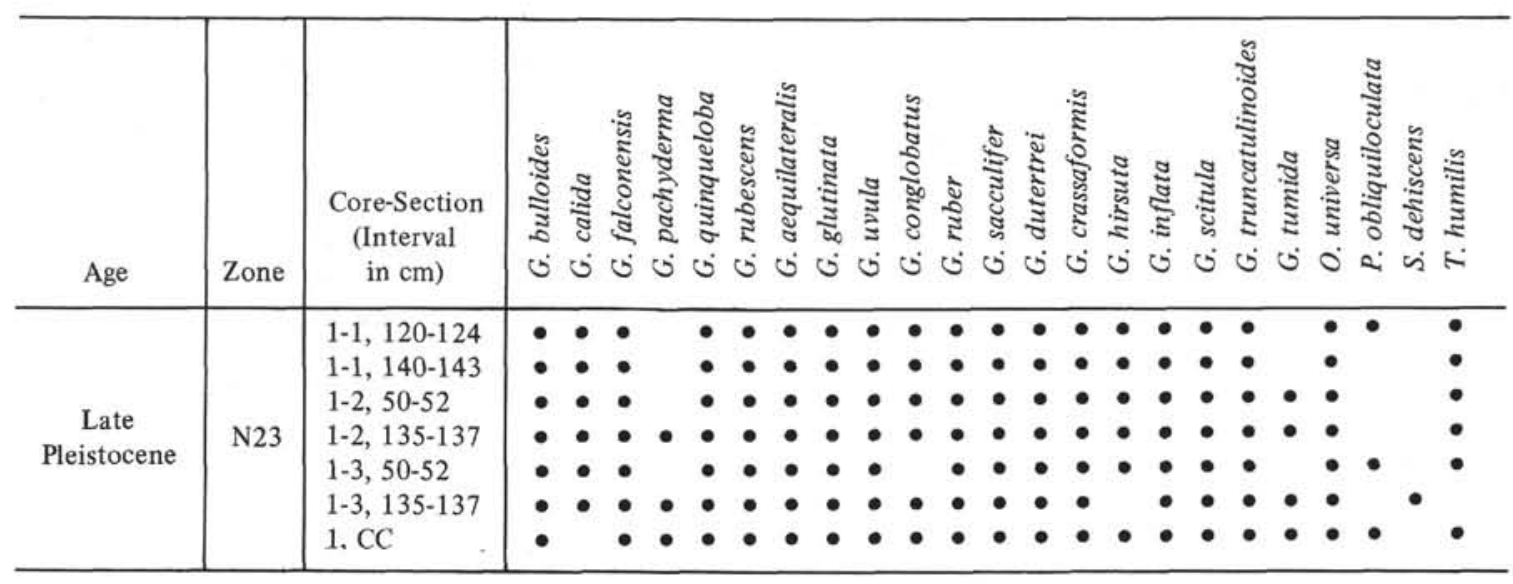

Figure 4. Planktonic foraminifera, Hole 332.

dominated by species which are indicative of temperate regions.

Sediments in Cores 2 and 3 are assigned to Zone N21 due to the presence of Globorotalia miocenica and the virtual absence of Sphaeroidinella seminulina and $S$. subdehiscens. Some samples in these cores contain rare specimens of $S$. seminulina and $S$. subdehiscens, and rare specimens of reworked Globorotalia margaritae. This situation also occurs in Hole 332A and has been discussed above. For the same reasons outlined above, the Zone N20/N21 boundary has been placed at the first downhole occurrence of several $S$. seminulina or $S$. subdehiscens. In Hole 333 this boundary lies within the washed interval between Cores 3 and 4 .

Cores 4 through 7 are assigned to Zone $\mathrm{N} 20$ based on the presence of common Sphaeroidinella seminulina and $S$. subdehiscens and on the absence of unmistakably in situ early Pliocene foraminifera. A total of 14 specimens of Globorotalia margaritae was found in samples from Cores 4 through 7. Most of these are abraded or discolored and are considered to be reworked contaminants.

The absolute age of the sediment-basement contact in Hole 333 is placed at 3.0 to 3.3 m.y.

\section{Hole 333A (Figure 7)}

This hole was drilled approximately 60 meters from Hole 333. A total of 2.5 meters of sediment was recovered above basement, and two samples were examined from these sediments. The samples are placed in Zone N20, based on the presence of common Sphaeroidinella seminulina and $S$. subdehiscens and on the absence of early Pliocene foraminifera.

\section{Site 334 (Figure 8)}

Site 334 was drilled in a small sediment-filled valley approximately $70 \mathrm{~km}$ west of Sites 332 and 333, and approximately $105 \mathrm{~km}$ west of the median valley of the Mid-Atlantic Ridge. At Site 334 a surficial punch core was recovered from the uppermost 6 meters of sediment. This was followed by a washed interval of 123.5 meters. Upper Miocene sediments with a thickness of 129.5 meters were then continuously cored above basement. Core 20, which was recovered from the basement sequence, contains a chalk interbed from which foraminifera were extracted.

Sediments in Core 1 are late Pleistocene in age and are assigned to Zone N23. The uppermost part of the core may be Holocene, but this could not be determined with certainty. The faunas of this core are dominated by temperate species, although some species indicative of warmer water are present.

The subdivision of Site 334 upper Miocene sediments into zones is made difficult by the absence of two of Blow's (1969) "N" zone marker species for the upper Miocene. Parker (1967) states that these two species, Globorotalia merotumida and Globorotalia plesiotumida, are "difficult to define and identify with assurance." Elsewhere (Miles, this chapter), it has been demonstrated that in Leg 37 foraminiferal samples continuous size gradations can be constructed from specimens which appear to be identical to these species to typical larger forms of Globorotalia cultrata. Additional difficulty arises from the co-occurrence in the lower part of the section of Globoquadrina advena and rare specimens of Globorotalia acostaensis. The former species occurs principally in the middle Miocene and is not known to occur above Zone N15, while $G$. acostaensis is not known to occur below Zone N16.

The heretofore unreported apparent overlap of these species occurs in Cores 13,14, and 20, and the interval is here assigned to the upper part of Zone N15. This assignment is based on the presence of numerous and readily identifiable specimens of $G$. advena. Specimens of $G$. acostaensis in these same cores are rare and often appear to grade morphologically into Globorotalia continuosa.

Core 2, which was collected below a washed interval of 123.5 meters, contains the youngest pre-Quaternary sediments recovered at Site 334. Determination of its exact stratigraphic position is made difficult by the discontinuous nature of coring at this site. In addition, Blow's zonal species cannot be used to determine its position because several upper Miocene and lower Pliocene " $N$ " zone marker species are absent from Leg 37 samples.

The best indicator of Core 2 stratigraphic position and age is Globigerinoides mitra. This species is almost 


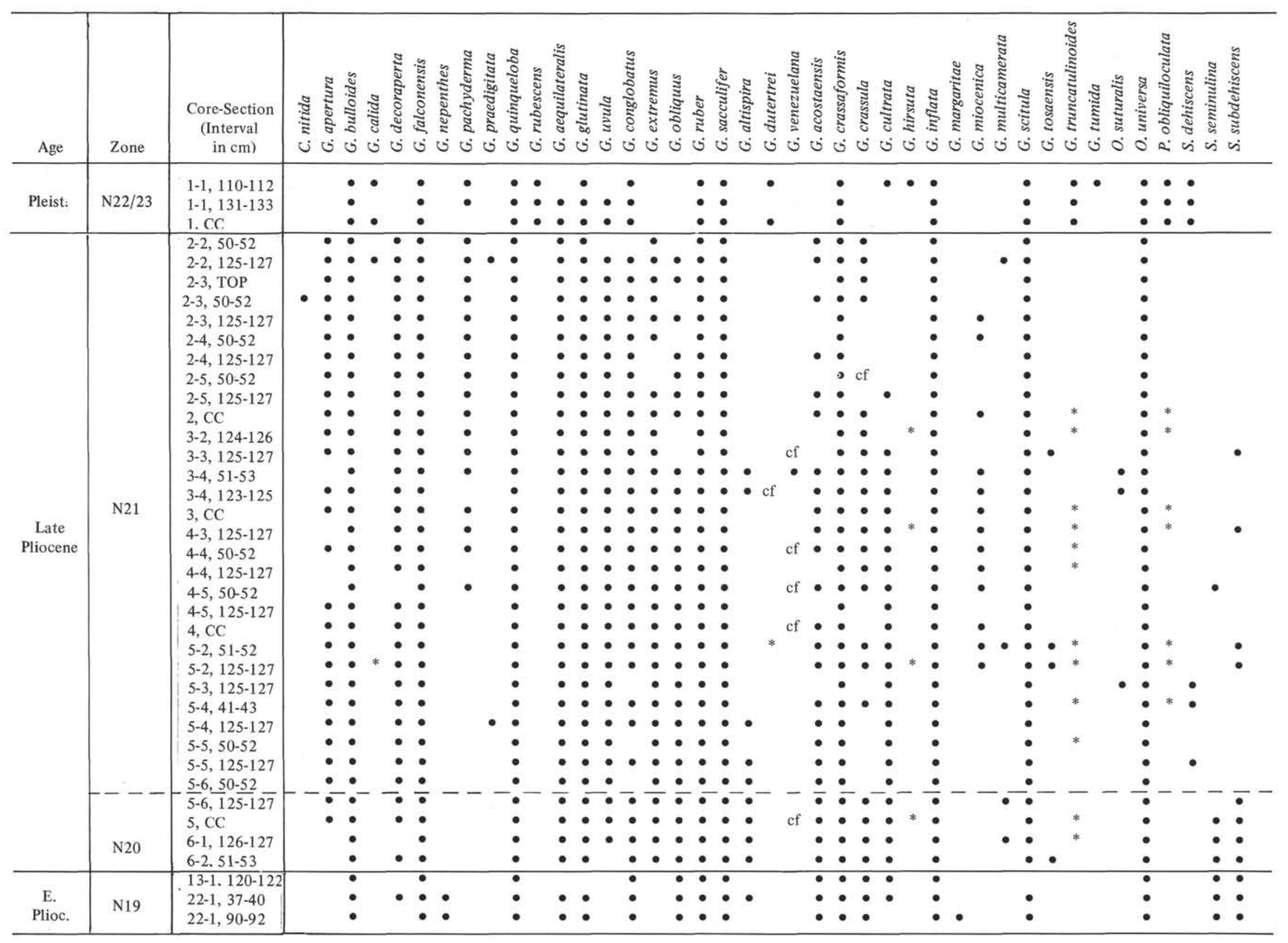

Figure 5. Planktonic foraminifera, Hole $332 \mathrm{~A} .^{*}=$ species represented only by drilling contaminants; $x=$ species represented only by reworked contaminants. 


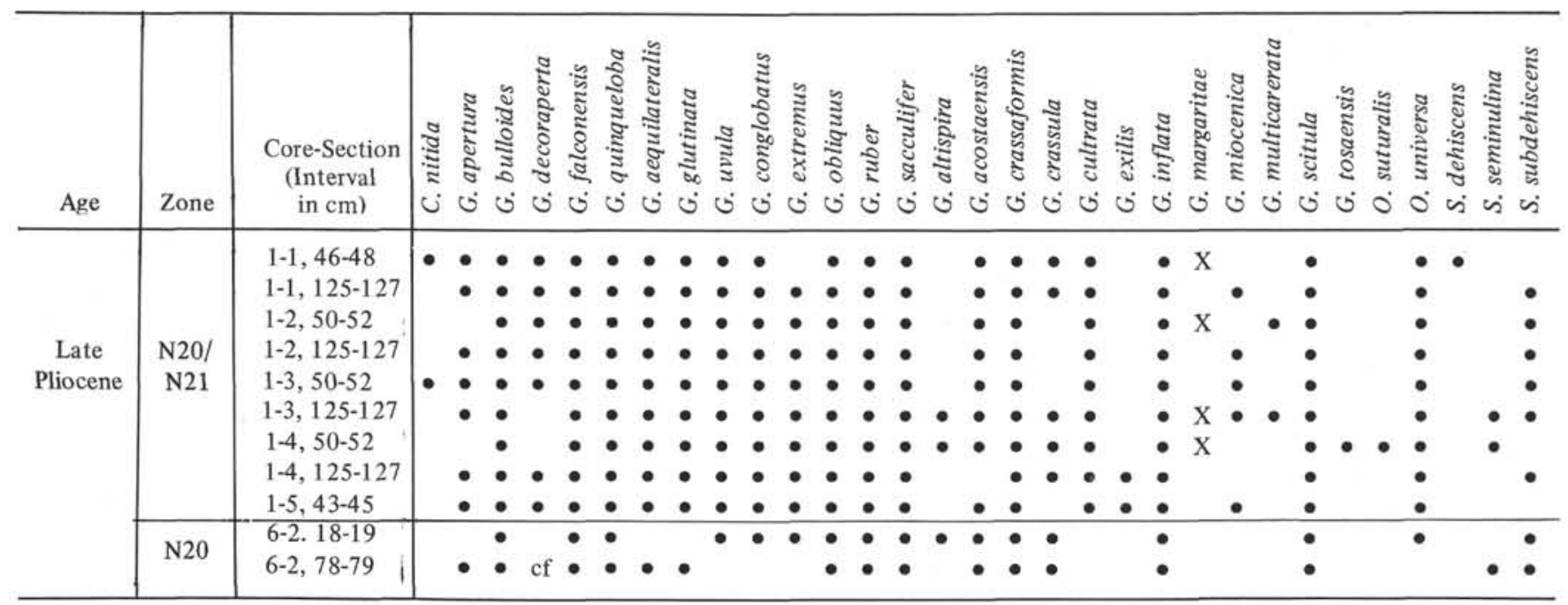

Figure 6. Planktonic foraminifera, Hole $332 \mathrm{~B} .{ }^{*}=$ species represented only by drilling contaminants; $X=$ species represented only by reworked contaminants.

entirely confined to the Miocene, although it is known to occur as high as Zone N18 (basal Pliocene) in the North Atlantic (Poag, 1972). Core 2 is assigned to Zone N17 of the upper Miocene. Although foraminiferal evidence for this is not strong, calcareous nannofossil floras appear to substantiate this conclusion.

The Zone N16/N17 boundary could not be determined by the use of foraminifera, but it was roughly established by using Radiolaria from core-catcher samples. It is placed between Cores 6 and 7, based on the first downhole occurrence of Ommartartus hughesi in Sample 334-7, CC.

Faunas in Cores 7 through 12 and Sample 334-13-1, $106-108 \mathrm{~cm}$ are assigned to Zone N16. The first downhole appearance of Globoquadrina advena is in Core 13, Section 2, marking the approximate top of Zone N15. Sediments in the interval between Sample $334-13-3,51-53 \mathrm{~cm}$ and basement are assigned to this zone.

The absolute age of the sediment-basement contact at Site 334 is approximately 10.5 to 11.0 m.y.

Foraminifera were recovered from moderately lithified sediments interbedded with basalt in Core 20, Section 2. The fauna is essentially the same as that found in Cores 13 and 14, and includes Globoquadrina advena and rare Globorotalia acostaensis. The co-occurrence of these species places this core in the early late Miocene.

\section{Site 335 (Figure 9)}

Site 335 was drilled on the western flank of the MidAtlantic Ridge approximately $170 \mathrm{~km}$ west of the median valley. Total penetration above basement was 455 meters, but most of this interval was washed. Five widely spaced cores were recovered from the interval between 87 and 455 meters (see Figure 3).

Core 1 is assigned to Zone $\mathrm{N} 21$ based on the presence of Globorotalia miocenica and the absence of Sphaeroidinella seminulina and $S$. subdehiscens.

At least two zones are represented in Core 2, and as many as three may be present. Sections 1,2 , and 3 are assigned to Zone N21 for the same reasons outlined for Core 1 . Zone N20 is either absent or is represented by a short interval. Several specimens of Sphaeroidinella seminulina and $S$. subdehiscens appear suddenly in Sample $335-2-4,50-52 \mathrm{~cm}$, which is questionably assigned to Zone N20. The next downhole sample, 335-2-4, 125-127 $\mathrm{cm}$, and nearly all remaining samples in Core 2 contain several specimens of Globorotalia margaritae. The interval containing this species is assigned to Zone N19. If Zone N20 exists at Site 335, it appears to have a thickness of less than 1.5 meters.

Due to the presence of a washed interval above Core 2 , it is impossible to ascertain whether Globorotalia margaritae, Sphaeroidinella seminulina, and S. subdehiscens make their first downhole appearances within the core. It is possible that their distributions are sporadic and that they are absent from the upper part of the core, but present elsewhere in the sediments above the cored interval. If this situation exists, the present zone assignments are not correct. In other Leg 37 holes, however, these species tend to remain common in nearly all samples below their first downhole appearances, except in cases where reworking is strongly suspected. This lack of sporadic distribution of in situ specimens in other holes suggests that the specimens in Section 4 of Core 2 represent the first downhole occurrences of these species, and that the present zone assignments are probably correct.

Core 3 is assigned to Zone N19. Sediments in this core contain common Globorotalia margaritae and some Globigerina nepenthes, but lack characteristic Miocene species.

Core 4, which was recovered approximately 85 to 95 meters below Core 3, contains foraminiferal faunas of late Miocene age which are assigned to Zone N17. This core contains rare specimens of the predominantly Miocene species, Globigerinoides mitra.

Core 5 contains one section of unconsolidated sediment which was recovered immediately above basement. It was collected below a washed interval of 123.5 meters, making a precise age determination difficult. 


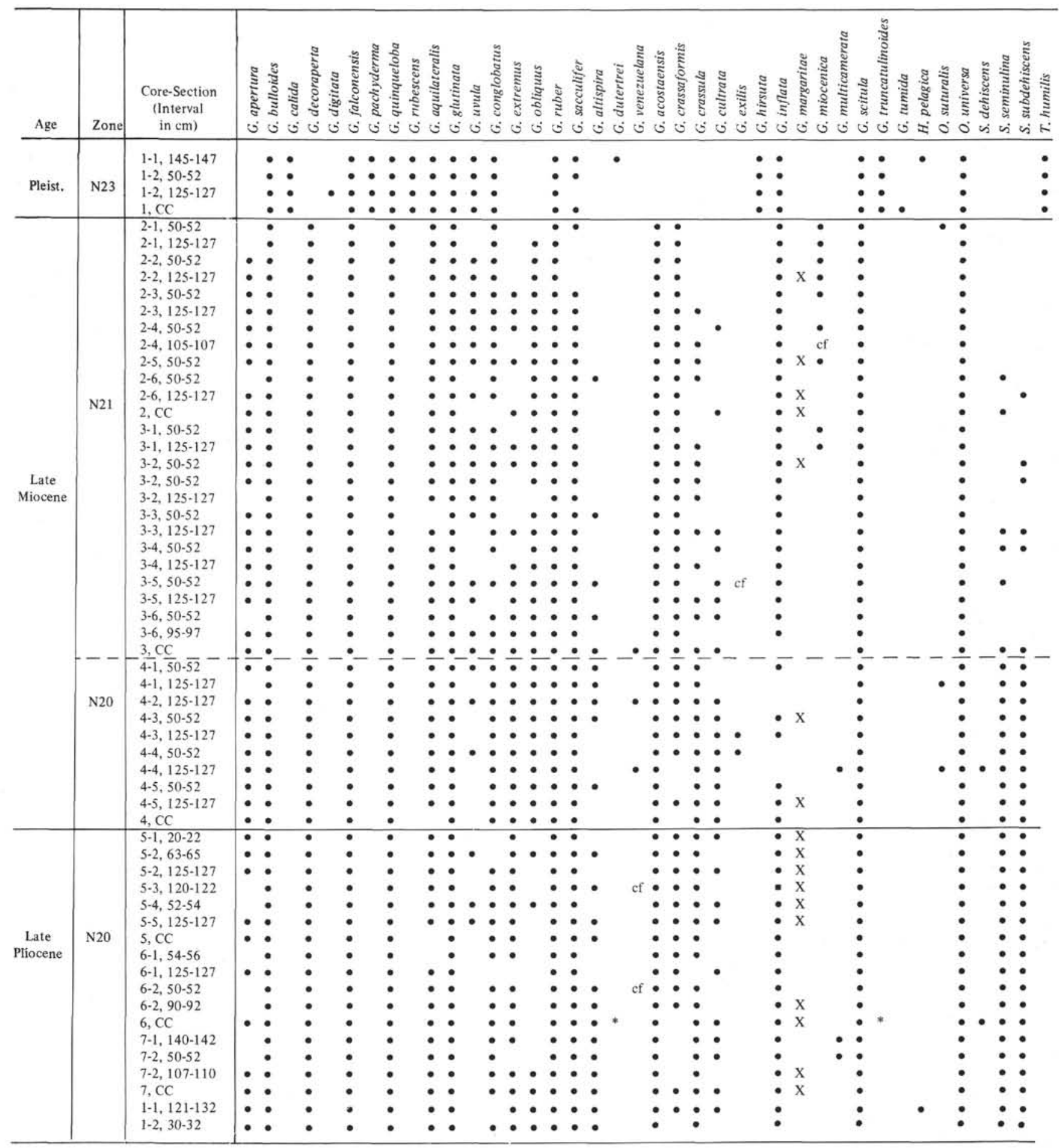

Figure 7. Planktonic foraminifera, Holes 333 and $333 A .^{*}=$ species represented only by drilling contaminants; $X=$ species represented only by reworked contaminants.

In terms of species represented, the foraminiferal faunas are similar to those immediately above basement at Site 334. However, the absence of unquestioned Globorotalia acostaensis and the presence of rare Globorotalia siakensis indicate that the sedimentbasement contact at Site 335 is older than that of Site 334. Rare specimens which resemble $G$. acostaensis are present in Core 5, but their test morphology is not suf- ficiently similar to typical forms of $G$. acostaensis to justify their inclusion in this species.

The presence of common Globigerina nepenthes in this core probably limits the age of basement to a maximum of $12.0 \mathrm{~m} . \mathrm{y}$. and limits the stratigraphic position to a maximum of lowermost Zone N14. The co-occurrence of this species and Globorotalia siakensis places this core in Zone N14. 
The absolute age of the sediment-basement contact at Site 335 is placed at 11.5 to 12.0 m.y.

\section{SYSTEMATICS}

The following section contains a listing of the species and subspecies of planktonic foraminifera which were encountered in Leg 37 samples. Genera, and the species and subspecies within each genus, have been listed in alphabetical order. The original reference and one or more additional references are given for each species. Readers are referred to Ellis and Messina (1940, et seq.) for original descriptions of genera and species.

Many of the taxa have been illustrated by scanning electron photographs (Plates 1-8).

\section{Genus CANDEINA d'Orbigny, 1839 \\ Candeina nitida d'Orbigny \\ (Plate 1, Figure 1)}

Candeina nitida d'Orbigny, 1839 , in de la Sagra, Hist. Phys. Pol. Nat.

Cuba, "Foraminiferes," p. 108, pl. 2, fig. 27, 28.

Candeina nitida d'Orbigny. Parker, 1967, Am. Paleontol. Am. Bull., v. 52 , p. 145, pl. 17 , fig. 1,2 .

This species occurs rarely in some Leg 37 samples. It is found most frequently in the upper Miocene sediments of Site 334, although isolated specimens are present in a few Pliocene and Pleistocene samples.

\section{Genus GLOBIGERINA d'Orbigny, 1826}

\section{Globigerina apertura Cushman}

(Plate 1, Figure 2)

Globigerina apertura Cushman, 1918, U.S. Geol. Surv., Bull., no. 676 , p. 57 , pl. 12 , fig. $8 \mathrm{a}-\mathrm{c}$.

Globigerina bulloides apertura Cushman. Blow, 1969, Intern. Conf.

Plankt. Microfoss., Proc., v. 1, p. 317.

Low-spired and high-spired forms of Globigerina apertura are present throughout Zones N15 and N21. The species is rare in nearly all of the samples in which it is found.

\section{Globigerina atlantica Berggren}

(Plate 1, Figures 3-5)

Globigerina atlantica Berggren, 1972, Initial Reports of the Deep Sea Drilling Project, v. 12, p. 972, pl. 1, fig. 1-7; pl. 2, fig. 5-8.

Specimens referable to Globigerina atlantica occur in a few samples of late Miocene age at Sites 334 and 335. Continuous size gradations can be seen in samples which contain several specimens. The smaller, immature specimens superficially resemble Globigerina pachyderma, but are generally larger at the same growth stage and exhibit differences in the characteristics of the aperture and wall structure. The larger forms resemble Globoquadrina dutertrei, but are more tightly coiled than this species and have a different wall texture.

\section{Globigerina bulloides d'Orbigny}

(Plate 1, Figures 6-8)

Globigerina bulloides d'Orbigny, 1826, Ann. Sci. Nat., ser. 1, v. 7, p. 277 , no. 1 , mod. 17,76 .

Globigerina bulloides d'Orbigny. Poag, 1972, Initial Reports of the Deep Sea Drilling Project, v. 11, p. 505, pl. 1, fig. 7, 8 .

Typical specimens of Globigerina bulloides range from Zone N15 to Zone N23 and occur in nearly every sample. Large forms of this species, some of which attain a maximum diameter of $1000 \mu \mathrm{m}$, are present in many samples of Pliocene age (Plate 1, Figure 7). In some Zone $\mathrm{N} 15$ and lower Zone N16 samples, G. bulloides variants are present which have a large final chamber and an aperture which is somewhat constricted (see Plate 1, Figure 8).

\section{Globigerina calida Parker}

(Plate 1, Figure 9)

Globigerina calida Parker, 1962, Micropaleontology, v. 8, p. 221, pl. 1, fig. 9-13, 15

Globigerina calida Parker. Jenkins and Orr, 1972, Initial Reports of the Deep Sea Drilling Project, v. 9, p. 1087, pl. 7, fig. 4, 5.
Specimens of Globigerina calida occur in most Leg 37 Pleistocene samples but are rare in samples of late Pliocene age. No specimens were found in situ in sediments beneath the upper Pliocene, although the recorded stratigraphic range of this species is Zone N17 to Zone N23 (Parker, 1967).

\section{Globigerina decoraperta Takayanagi and Saito}

(Plate 1, Figure 10)

Globigerina druryi Akers decoraperta Takayanagi and Saito, 1962, Tohoku Univ. Sci. Rept., sec. ser. (Geol.), sp. v. 5, p. 85, pl. 28, fig. 10.

Globigerina decoraperta Takayanagi and Saito. Parker, 1967, Am.

Paleontol. Bull., v. 5, p. 149, pl. 19, fig. 1.

Globigerina decoraperta is present in many Miocene and Pliocene samples. The species, because of its generalized form, is sometimes difficult to distinguish from other globigerinid species, especially white forms of Globigerina rubescens. The species is rare in most of the samples in which it is found and never occurs in abundance.

\section{Globigerina digitata Brady}

(Plate 1, Figures 11-13)

Globigerina digitata Brady, 1879, Quart. J. Micr. Sci., new ser., v. 19, p. 286.

Globigerina digitata Brady. Parker, 1962, Micropaleontology, v. 8, p. 222 , pl. 1, fig. $20-25$.

A total of four specimens of Globigerina digitata were found in Leg 37 samples. All specimens are from sediments assigned to Zone N23. Two of these, found in Sample 334-1-2, 50-52 cm, are not digitate and may represent juveniles of the species, or they may be late forms of Globigerina praedigitata.

\section{Globigerina falconensis Blow}

(Plate 1, Figure 14)

Globigerina falconensis Blow, 1959, Am. Paleontol. Bull., v. 39, p. 177 , pl. 9 , fig. 40,41

Globigerina falconensis Blow. Parker, 1967, Am. Paleontol. Bull., v. 52 , p. 150 , pl. 19 , fig. 11 .

This species is present in nearly all of the samples examined for foraminifera. Although never abundant, it is common in many of the samples.

\section{Globigerina nepenthes Todd}

(Plate 1, Figures 15, 16)

Globigerina nepenthes Todd, 1957, U.S. Geol. Surv., Prof. Paper 280H, p. 301 , pl. 78 , fig. 7 .

Globigerina nepenthes Todd. Blow, 1969, Intern. Conf. Plankt. Microfoss., Proc., v. 1, p. 320 , pl. 14, fig. 5.

This species is present in all Leg 37 samples of Miocene age and in many samples of early Pliocene age. Most specimens of $G$. nepenthes possess the characteristic protruding thumblike final chamber, although a number of Miocene samples contain specimens in which the final chamber is neither thumblike nor obviously protruding. In the samples in which the latter forms occur, complete gradations between these forms and typical $G$. nepenthes can be seen.

\section{Globigerina pachyderma (Ehrenberg)}

(Plate 1, Figures 17-19)

Aristerospira pachyderma Ehrenberg, 1861, K. Preuss. Akad. Wiss. Berlin, Monatsber., p. 303.

Globigerina pachyderma (Ehrenberg). Parker, 1962, Micropaleontology, v. 8 , p. 224 , pl. 1 , fig. $26-35$; pl. 2, fig. 1-6.

Globiergina pachyderma is not common in any Leg 37 samples. It is most often encountered in samples of Pleistocene age, although it is also present in a few Pliocene and late Miocene samples.

\section{Globigerina praedigitata Parker}

(Plate 2, Figures 1, 2)

Globigerina praedigitata Parker, 1967, Am. Paleontol. Bull., v. 52, p. 151 , pl. 19, fig. 5-8.

Globigerina praedigitata Parker, Jenkins and Orr, 1972, Initial Reports of the Deep Sea Drilling Project, v. 9, p. 1089, pl. 8, fig. 79.

Isolated specimens of $G$. praedigitata were found in four samples ranging from Zone N17 to Zone N21. 


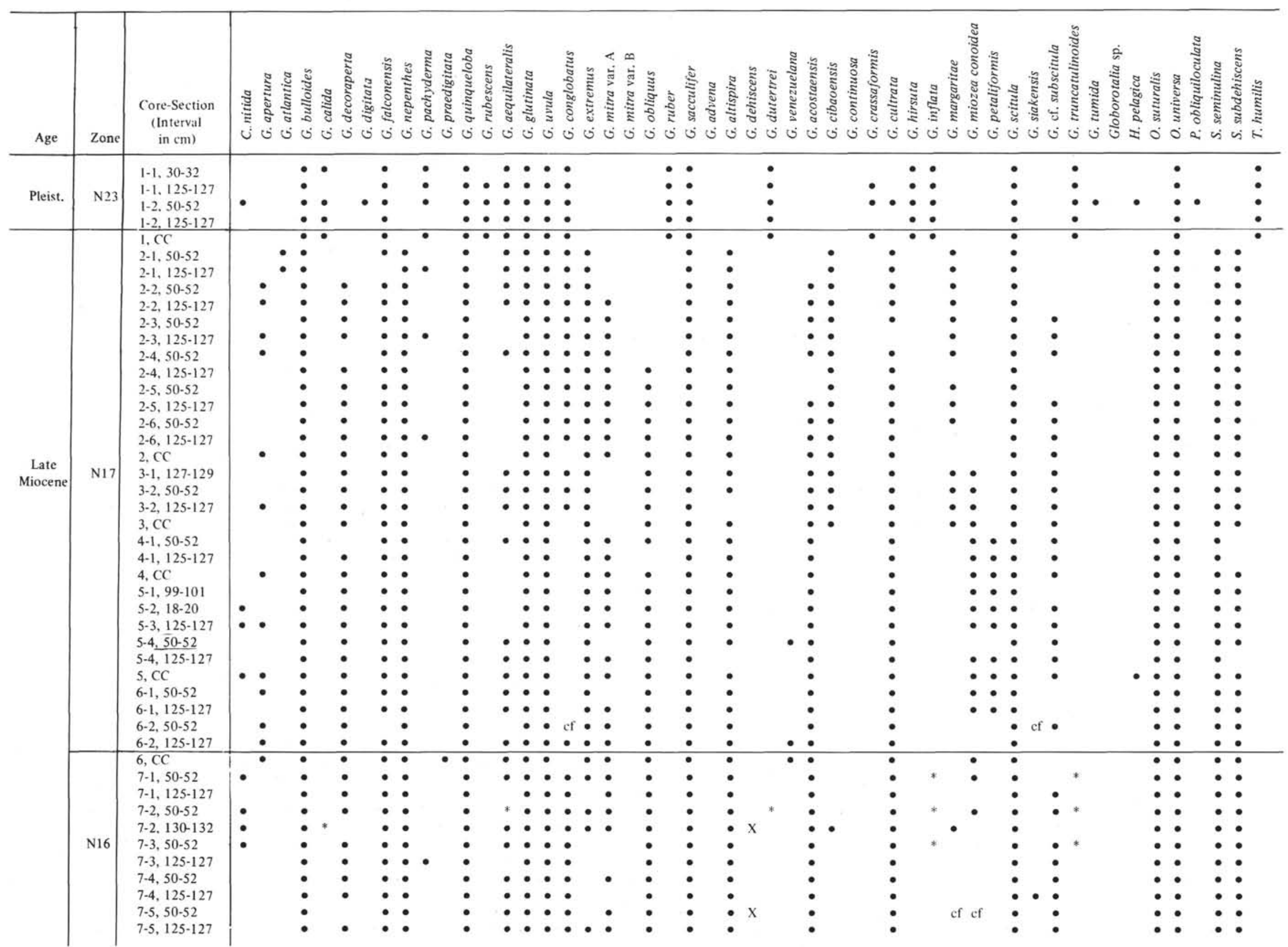




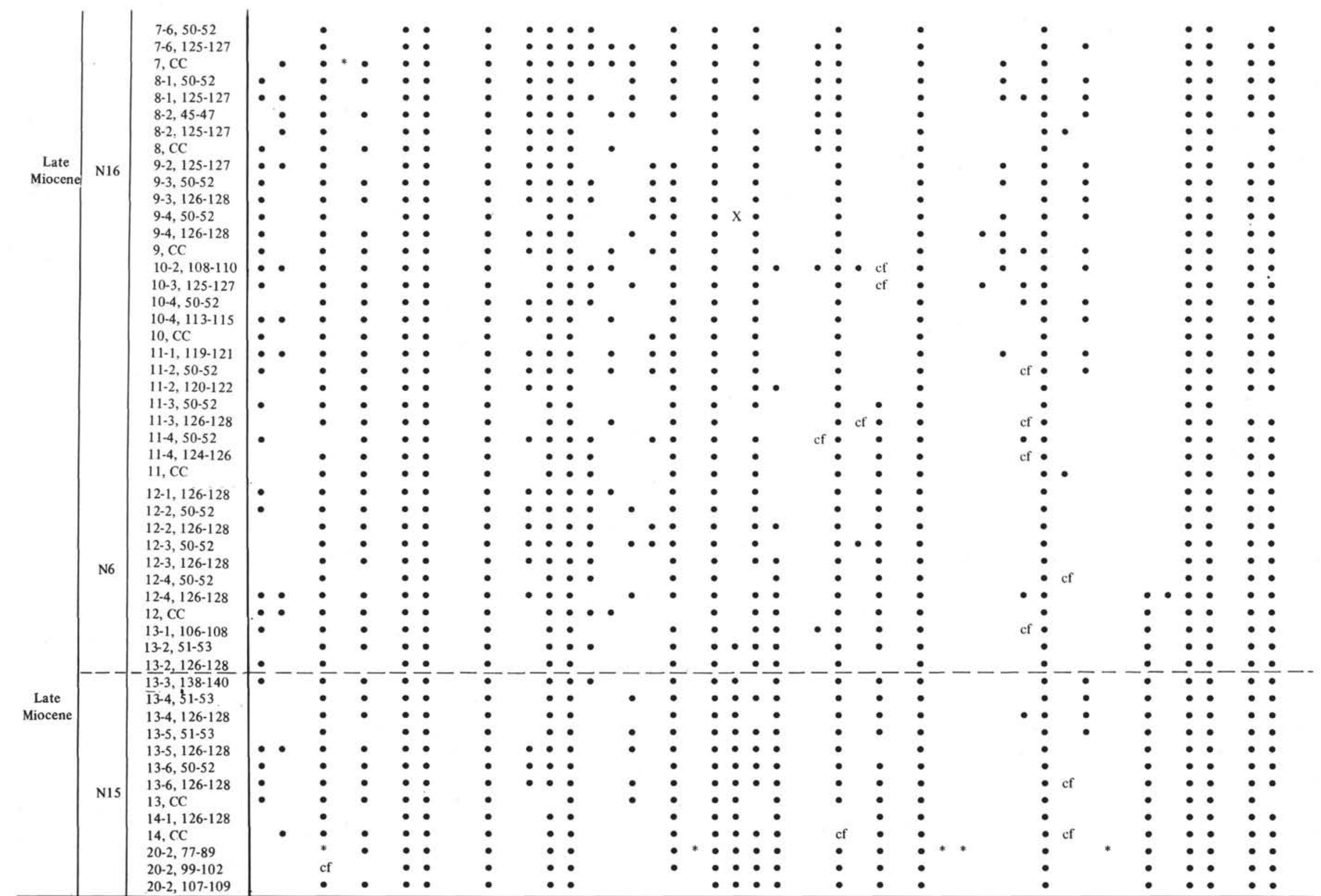




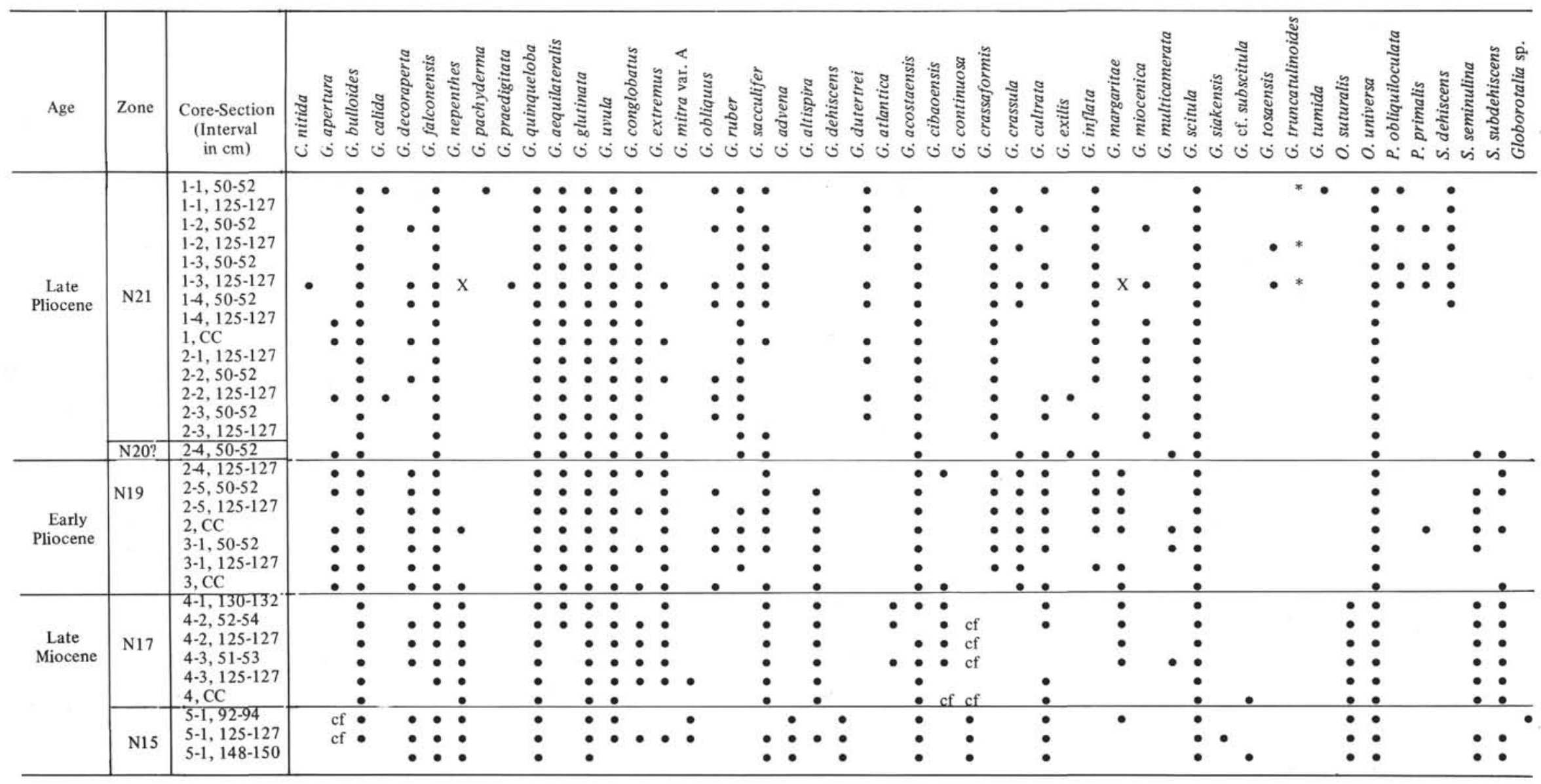

Figure 9. Planktonic foraminifera, Site 335. ${ }^{*}=$ species represented only by drilling contaminants; $\mathrm{X}=$ species represented only by reworked contaminants. 


\section{Globigerina quinqueloba Natland}

(Plate 2, Figures 3-6)

Globigerina quinqueloba Natland, 1938, Scripps Inst. Oceanogr. Bull., Tech. Ser., v. 4, p. 149, pl. 6, fig. 18-21.

Globigerina quinqueloba Natland. Boltovskoy, 1974, Initial Reports of the Deep Sea Drilling Project, v. 26, p. 703, pl. 3, fig. 1, 2.

Globigerina quniqueloba is present in all Leg 37 samples which were examined for foraminifera. Larger specimens similar to the holotype are restricted to samples of Pleistocene age, but minute specimens are abundant in the small-size fraction of nearly every sample.

\section{Globigerina rubescens Hofker}

(Plate 2, Figure 7)

Globigerina rubescens Hofker, 1956, Spolia Zool. Mus. Hauniensis, v. 15 , p. 234 , pl. 35 , fig. $18-21$.

Globigerina rubescens Hofker. Parker, 1967, Am. Paleontol. Bull., v. 52 , p. 152 , pl. 19 , fig. 3,4 .

Globigerina rubescens is present in nearly every sample of Pleistocene age. The species has been reported from the Pliocene (Blow, 1969), but it could not be identified with certainty in Leg 37 samples of this age.

\section{Genus GLOBIGERINELLA Cushman, 1927}

\section{Globigerinella aequilateralis (Brady)}

(Plate 2, Figures 8-10)

Globigerina aequilateralis Brady, 1879, Quart. J. Micr. Sci., new ser., v. 19 , p. 285 .

Globigerinella aequilateralis (Brady). Boltovskoy, 1974, Initial Reports of the Deep Sea Drilling Project, v. 26, p. 703, pl. 3, fig. 3 .

This species is present in samples ranging from Zone $\mathrm{N} 15$ to Zone $\mathrm{N} 23$. It occurs in nearly all samples of Pliocene and Pleilocene age and is sometimes common in these samples. Globigerinella aequilateralis is usually absent or poorly represented in samples of late Miocene age.

\section{Genus GLOBIGERINITA Bronnimann, 1951}

\section{Globigerinita glutinata (Egger)}

(Plate 2, Figures 11-13)

Globigerina glutinata Egger, 1893, Abh. K. Bayer. Akad. Wiss. Munchen, CLII, v. 18, p. 371, pl. 13, fig. 19-21.

Globigerinita glutinata (Egger). Parker, 1962, Micropaleontology, v. 8 , p. 246 , pl. 9 , fig. $1-16$.

Globigerinita glutinata is present in nearly all samples, and is abundant in the small-size fractions of many samples.

\section{Globigerinita uvula (Ehrenberg)}

(Plate 2, Figure 14)

Pylodexia uvula Ehrenberg, 1861, K. Preuss. Akad. Wiss. Berlin, Monatber., p. 276, 277, 308.

Globigerinita uvula (Ehrenberg). Parker, 1962, Micropaleontology, v. 8 , p. 252 , pl. 8 , fig. $14-26$. ples.

This species occurs in the small-size fractions of nearly all sam-

\section{Genus GLOBIGERINOIDES Cushman, 1927}

\section{Globigerinoides conglobatus (Brady)}

(Plate 2, Figure 15)

Globigerina conglobata Brady, 1879, Quart. J. Micr. Sci., new ser., v. 19 , p. 286

Globigerinoides conglobatus (Brady). Jenkins and Orr, 1972, Initial Reports of the Deep Sea Drilling Project, v. 9, p. 1092, pl. 14, fig. 4,5 .

Globigerinoides conglobatus occurs regularly in samples of Pliocene and Pleistocene age, but is rare and sporadic in late Miocene samples. Two deviations from typical $G$. conglobatus were noted in samples from the upper Miocene. One variant has a lax mode of coiling and large secondary apertures. The other variant is small form which often superficially resembles atypical forms of Globigerina nepenthes in size, shape, and surface texture.
Globigerinoides extremus Bolli and Bermudez

(Plate 2, Figures 16, 17)

Globigerinoides obliquus extremus Bolli and Bermudez, 1965, Bol. Inf., Assoc. Venez. Geol., Min. Pet., v. 8, p. 159, pl. 1, fig. 10-12. Globigerinoides extremus Bolli and Bermudez. Poag, 1972, Initial Reports of the Deep Sea Drilling Project, v. 11, p. 507, pl. 7 . fig. 1,2 . ples.

This species is present in most late Miocene and Pliocene sam-

\section{Globigerinoides mitra Todd var. A}

(Plate 3, Figures 1-3)

Globigerinoides mitra Todd, 1957, U.S. Geol. Surv., Prof. Paper 280H, p. 302 , pl. 78 , fig. 3,6 .

Globigerinoides mitra Todd. Poag, 1972, Initial Reports of the Deep Sea Drilling Project, v. 11, p. 507, pl. 7, fig. 1, 2.

This variety of Globigerinoides mitra has been reported from the North Atlantic by Poag (1972). It is present in Leg 37 samples at Sites 334 and 335 . At the former site is occurs in nearly half of the late Miocene samples, and at the latter site it occurs rarely in three samples of Miocene age. The characteristic wall texture allows easy identification even of small fragments, and most specimens are represented by such fragments. In addition to the typical high-spired forms, a number of globular, low-spired specimens are also present in the samples.

\section{Globigerinoides mitra Todd var. B}

(Plate 3, Figure 4, 5)

Globigerinoides mitra Todd, 1957, U.S. Geol. Surv., Prof. Paper 280H, p. 302 , pl. 78 , fig. 3,6 .

Globigerinoides mitra Todd. Jenkins and Orr, 1972, Initial Reports of the Deep Sea Drilling Project, v. 9, p. 1092, pl. 14, fig. 6, 7.

Globigerinoides mitra Todd. Boltovskoy, 1974, Initial Reports of the Deep Sea Drilling Project, v. 26, p. 704, pl. 5, fig. 1, 2.

Globigerinoides mitra var. B is present in several late Miocene samples at Site 334. This variety differs from G. mitra var. A in having a more highly spired test, smaller chambers in the final whorl, smaller primary and secondary apertures, and in having a smoother wall texture. The specimens agree well with those illustrated by Boltovskoy (1974) and Jenkins and Orr (1972).

\section{Globigerinoides obliquus Bolli}

(Plate 3, Figure 6)

Globigerinoides obliquus Bolli, 1957, U.S. Natl. Mus. Bull. 215, p. 113 , pl. 25 , fig. 9,10 ; p. 112 , fig. 21.

Globigerinoides obliquus obliquus Bolli. Krasheninnikov and Hoskins,

1973, Initial Reports of the Deep Sea Drilling Project, v. 20, p. 128 , pl. 14 , fig. 5,6 .

This species occurs in late Miocene and Pliocene samples of all sites. It is rare in nearly all of the samples in which it occurs.

\section{Globigerinoides ruber (d'Orbigny)}

(Plate 3, Figures 7, 8)

Globigerina rubra d'Orbigny, 1839, in de la Sagra, Hist. Phys. Pol. Nat. Cuba, "Foraminiferes," p. 82, pl. 4, fig. 12-14.

Globigerinoides ruber (d'Orbigny). Parker, 1962, Micropaleontology, v. 8 , p. 230 , pl. 3 , fig. $11-14$; pl. 4 , fig. 1-10.

This species occurs in the Pliocene and Pleistocene of all sites, but is absent from samples of Miocene age. Forms which have been assigned to Globigerinoides elongatus and Globigerinoides pyramidalis by some workers are considered to be variants of $G$. ruber and have been included with that species in this report.

\section{Globigerinoides sacculifer (Brady)}

(Plate 3, Figures 9-11)

Globigerina sacculifera Brady, 1877, Geol. Mag., new ser., v. 4, p. 535 .

Globigerinoides sacculifer (Brady). Parker, 1967, Am. Paleontol.

Bull., v. 52, p. 156 , pl. 21 , fig. 1, 2, 4

This species is present in nearly all Leg 37 samples. Its abundance in these samples is highly variable. Variants which are often referred to the species Globigerinoides trilobus and Globigerinoides immaturus are included in the species $G$. sacculifer in this report. This has been done because it seems unrealistic to separate saccate forms taxo- 
nomically from essentially identical forms which do not bear sacs or have not yet developed them.

\section{Genus GLOBOQUADRINA Finlay, 1947}

\section{Globoquadrina advena Bermudez}

(Plate 3, Figure 12)

Globoquadrina quadraria var. advena Bermudez, 1949, Cushman Lab. Foram. Res., Spec. Publ. no. 25, p. 287, pl. 22, fig. 36-38.

Globoquadrina advena Bermudez. Paog, 1972, Initial Reports of the Deep Sea Drilling Project, v. 11, p. 513, pl. 8, fig. 3, 4.

This species is present at Sites 334 and 335 in sediments immediately above basement. In the North Atlantic $G$. advena occurs stratigraphically as high as the lower part of the upper Miocene (Poag, 1972). The species aided greatly in determining stratigraphic position within the upper Miocene at Site 334.

\section{Globoquadrina altispira (Cushman and Jarvis)}

(Plate 3, Figures 13-15)

Globigerina altispira Cushman and Jarvis, 1936, Contrib. Cushman Lab. Foram. Res., v. 12, p. 5, pl. 1, fig. 13, 14.

Globoquadrina altispira (Cushman and Jarvis). Jenkins and Orr, 1972, Initial Reports of the Deep Sea Drilling Project, v. 9, p. 1094, pl. 17, fig. 5-7.

Globoquadrina altispira is present only occasionally in late Pliocene samples, but is found in most samples of Miocene and early Pliocene age.

\section{Globoquadrina dehiscens (Chapman, Parr, and Collins)}

(Plate 3, Figures 16-19)

Globorotalia dehiscens Chapman, Parr, and Collins, 1934, Linn. Soc. London (Zool.), v. 38, p. 569, pl. 11, fig. 36.

Globoquadrina dehiscens (Chapman, Parr, and Collins). Poag, 1972, Initial Reports of the Deep Sea Drilling Project, v. 11, p. 514, pl. 8 , fig. 6,7 .

Typical specimens of the species are present in several Miocene samples at Sites 334 and 335. Although the species is known to occur as high as the Miocene-Pliocene boundary in other areas, it is almost totally confined to Zones N14, N15, and lower N16 in Leg 37 samples.

\section{Globoquadrina dutertrei (d'Orbigny)}

(Plate 4, Figures 1-3)

Globigerina rotundata d'Orbigny, 1826, Ann. Sci. Nat., ser. 1, v. 7, p. 277 , no. 6 (nomen nudum).

Globigerina dutertrei d'Orbigny, 1839, Hist. Phys. Pol. Nat. Cuba, "Foraminferes," p. 84, pl. 4, fig. 19-21.

Globigerina eggeri Rhumbler, 1901, Nordisches Plankton, Leif 1, p. 19 , fig. 20.

Globoquadrina dutertrei (d'Orbigny). Parker, 1967, Am. Paleontol.

Bull., v. 52 , p. 168 , pl. 25 , fig. 7 .

This species is present in a few samples of late Pliocene and Pleistocene age.

\section{Globoquadrina venezuelana (Hedberg)}

(Plate 4, Figures 4-6)

Globigerina venezuelana Hedberg, 1937, J. Paleontol., v. 11, p. 681, pl. 92, fig. 7.

Globoquadrina venezuelana (Hedberg). Parker, 1967, Am. Paleontol. Bull., v. 52, p. 171 , pl. 26, fig. 4-10.

Specimens of Globoquadrina venezuelana are present in a few late Miocene and Pliocene samples. Many specimens are atypical in that the test has a diminutive final chamber which often bears a liplike structure and a primary aperture which is nearly closed.

\section{Genus GLOBOROTALIA Cushman, 1927}

\section{Globorotalia acostaensis Blow}

(Plate 4, Figure 7)

Globorotalia acostaensis Blow, 1959, Am. Paleontol. Bull., v. 39, p. 208, pl. 17, fig. 106.

Globorotalia acostaensis Blow. Boltovskoy, 1974, Initial Reports of the Deep Sea Drilling Project, v. 26, p. 705, pl. 8, fig. 1-4.
This species is present in nearly all samples from the upper Miocene and Pliocene, although it is rare in the lower part of the upper Miocene. Its presence in sediments immediately above basement at Site 334 indicates a late Miocene age for the sediment-basement contact at this site. Rare specimens which are questionably assigned to this species also occur immediately above basement at Site 335 . These specimens are similar to $G$. acostaensis in the number of chambers and in their general mode of coiling, but in most cases characteristics of the aperture and umbilical area are unlike those of typical $G$. acostaensis.

\section{Globorotalia cibaoensis Bermudez}

(Plate 4, Figures 8-10)

Globorotalia cibaoensis Bermudez, 1949, Cushman Lab. Foram. Res., Spec. Publ., no. 25, p. 285, pl. 22, fig. 21-23.

Globorotalia (Globorotalia) miozea cibaoensis Bermudez. Blow, 1969, Intern. Conf. Plankt. Microfoss., Proc., v. 1, p. 366, pl. 8, fig. 49 ; pl. 45 , fig. 8.

This species occurs most frequently in samples of late Miocene age from Sites 334 and 335 .

\section{Globorotalia continuosa Blow}

(Plate 4, Figures 11-13)

Globorotalia opima continuosa Blow, 1959, Am. Paleontol. Bull., v. 39 , p. 218 , pl. 19 , fig. 125 .

Globorotalia continuosa Blow. Jenkins and Orr, 1972, Initial Reports of the Deep Sea Drilling Project, v. 9, p. 1097, pl. 21, fig. 1-3. Globorotalia continuosa could be identified with certainty only in the lowermost samples from Sites 334 and 335 . However, forms closely resembling this species occur throughout the upper Miocene at these sites.

\section{Globorotalia crassaformis (Galloway and Wissler) (Plate 4, Figures 14-16)}

Pulvinulina crassa Brady, 1884, Rept. Voy. Challenger, Zool., v. 9, p. 694 , pl. 103, fig. 11,12 .

Globigerina crassaformis Galloway and Wissler, 1927, J. Paleontol., v. 1 , p. 41 , pl. 7, fig. 12 .

Globorotalia (Turborotalia) oceanica Cushman and Bermudez, 1949, Contrib. Cushman Lab. Foram. Res., v. 25, p. 43, pl. 8, fig. 1315.

Globorotalia (Turborotalia) crassaformis crassaformis (Galloway and Wissler). Blow, 1969, Intern. Conf. Plankt. Micrfoss., Proc., v. 1, p. 347 , pl. 4 , fig. $1-3$; pl. 37 , fig. 1-4.

Globorotalia (Turborotalia) crassaformis ronda Blow, 1969, Intern. Conf. Plankt. Microfoss., Proc., v. 1, p. 348, pl. 4, fig. 4-6; pl. 37 , fig. 6-9.

This species is present in most Pliocene and Pleistocene samples. Many specimens which closely resemble Globorotalia truncatulinoides and $G$. tosaensis occur in samples of late Pliocene age from Site 332 .

\section{Globorotalia crassula Cushman and Stewart}

(Plate 4, Figures 17-19)

Globorotalia crassula Cushman and Stewart, 1930, San Diego Soc. Nat. Hist., Trans., v. 6, p. 77, pl. 7, fig. 1.

Globorotalia crassula Cushman and Stewart. Boltovskoy, 1974, Initial Reports of the Deep Sea Drilling Project, v. 26, p. 705, pl. 8, fig. 12-17.

This species is restricted to the Pliocene in Leg 37 samples. It is most common in Zones N19 and N20.

\section{Globorotalia cultrata (d'Orbigny) \\ (Plate 5, Figures 1-3)}

Rotalia (Rotalia) menardii d'Orbigny, 1826, Ann. Sci. Nat., ser. 1, v. 7 , p. 273

Rotalina (Rotalina) cultrata d'Orbigny, 1839, in de la Sagra, Hist. Phys. Pol. Nat. Cuba, "Foraminiferes," p. 76, pl. 5, fig. 7-9.

Globorotalia cultrata (d'Orbigny). Parker, 1967, Am. Paleontol. Bull., v. 52 , p. 177 , pl. 31 , fig. $2,3$.

Globorotalia cultrata is nearly absent in Leg 37 Pleistocene sediments, but is present throughout most of the Miocene and Pliocene. In most of the samples in which it is present it is repre- 
sented by no more than a few specimens, although it is common in some samples of Miocene age. Forms referred to Globorotalia cultrata limbata have been included with $G$. cultrata because the two taxa could not be consistently distinguished with certainty.

\section{Globorotalia exilis Blow \\ (Plate 5, Figures 4, 5)}

Globorotalia (Globorotalia) cutrata exilis Blow, 1969, Intern. Conf. Plankt. Microfoss., Proc., v. 1, p. 396, pl. 7, fig. 1-3; pl. 42, fig. 1,5 .

Globorotalia exilis Blow. Jenkins and Orr, 1972, Initial Reports of the Deep Sea Drilling Project, v. 9, p. 1098, pl. 23, fig. 1-9.

Only ten specimens of $G$. exilis were recognized in Leg 37 samples. All occurrences are from the Pliocene.

\section{Globorotalia hirsuta (d'Orbigny)}

(Plate 5, Figures 6-8)

Rotalina hirsuta d'Orbigny, 1839, in Barker-Webb and Berthelot, Hist. Nat. Iles Canaries, "Foraminiferes," v. 2, p. 131, pl. 1, fig. 37-39.

Globorotalia hirsuta (d'Orbigny). Parker, 1967, Am. Paleontol. Bull., v. 52 , p. 178 , pl. 32 , fig. 3 .

This species is restricted to the Pleistocene in Leg 37 samples.

\section{Globorotalia inflata (d'Orbigny)}

(Plate 5, Figures 9-15)

Globigerina inflata d'Orbigny, 1839, in Barker-Webb and Berthelot, Hist. Nat. Iles Canaries, "Foraminiferes," v. 2, p. 134, pl. 2, fig. 7-9.

Globorotalia inflata (d'Orbigny). Parker, 1962, Micropaleontology, v. 8 , p. 236 , pl. 5 , fig. $6-9$.

This species is present in nearly all samples of Pliocene and Pleistocene age, but is absent from Miocene samples. Some specimens referable to Globorotalia puncticulata are present in samples of Pliocene age, but these are included in the species $G$. inflata in this report. A variant of the $G$. inflata group occurs in several Leg 37 Pliocene samples (see Plate 5, Figures 12-15). A few samples contain a large number of these forms, but in most cases they are rare. This variant has four to six chambers in the final whorl, and is often nearly circular in equatorial profile. Complete gradations from the multichambered forms to typical Pliocene forms of $G$. inflata can be observed in some samples.

\section{Globorotalia margaritae Bolli and Bermudez}

(Plate 5, Figures 16-18)

Globorotalia margaritae Bolli and Bermudez, 1965, Bol. Inf., Assoc. Venez. Geol., Min. Pet., v. 8, p. 139, pl. 1, fig. 16-18.

Globorotalia (Globorotalia) margaritae Bolli and Bermudez. Blow,

1969, Intern. Conf. Plankt. Microfoss., Proc., v. 1, p. 363, pl. 44,

fig. $1-6$; pl. 45 , fig. $1-3,5,6$.

This species is present in many late Miocene and early Pliocene samples. It is useful in distinguishing sediments of early Pliocene age from those of late Pliocene, although in some Leg 37 samples rare reworked specimens in the upper Pliocene often confused stratigraphic interpretation.

\section{Globorotalia miocenica Plamer}

(Plate 6, Figures 1-3)

Globorotalia menardii var. miocenica Palmer, 1945, Am. Paleontol. Bull., v. 29 , p. 70 , pl. 1, fig. 11.

Globorotalia miocenica Palmer. Poag, 1972, Initial Reports of the

Deep Sea Drilling Project, v. 11, p. 510, pl. 3, fig. 3, 4

Globorotalia miocenica is rare in Leg 37 samples, and is restricted to Zone N21. The species is known from sediments elsewhere in the Atlantic/Caribbean Province which range from Zone N17 to Zone N22 (Blow, 1969; Smith and Beard, 1973).

Scattered globorotalid specimens which superficially resemble $G$. miocenica are found in some samples of late Miocene age from Site 334. A typical specimen has a flat dorsal side, a conical umbilical side, and five chambers in the outer whorl (Plate 6, Figures 12, 14, 16). Characteristics of the umbilical side, especially, indicate that these globorotalid specimens are not referable to $G$. miocenica. The umbilical side of the final chamber of G. miocenica is low and rounded in the adult stage and hardly protrudes below the level of the previous chambers. In the late Miocene specimens, however, the umbilical side is more highly conical than in typical $G$. miocenica and the umbilical side of the final chamber is much more acutely angled. In most specimens the final chamber protrudes below the level of the previous chambers. In addition, the characteristic appearance of the umbilical side of G. miocenica and the round, open, deep umbilicus of this species are lacking in the late Miocene specimens.

It is the opinion of the writer that these specimens are not closely related to G. miocenica, but rather belong to Globorotalia petaliformis. In some specimens the final chamber forms a steplike structure on the dorsal side of the test. This is a major $G$. petaliformis characteristic, and can be seen in various stages of development leading to typical forms of that species. In addition, these specimens occur within the range of $G$. petaliformis at Site 334, and their quantitative fluctuations from sample to sample are closely tied to those of $G$. petaliformis.

\section{Globorotalia miozea conoidea Walters}

(Plate 6, Figures 4, 5)

Globorotalia miozea conoidea Walters, 1965, New Zeland J. Geol. Geophys., v. 8, p. 124, fig. 8, I-M

Globorotalia miozea conoidea Walters. Boltovskoy, 1974, Initial Reports of the Deep Sea Drilling Project, v. 26, p. 707, pl. 11, fig. 5-18.

This subspecies occurs in the upper Miocene of Site 334. It is most frequently encountered in Zone N17, although occasional specimens are also found in Zone N16.

\section{Globorotalia multicamerata Cushman and Jarvis (Plate 6, Figures 6-8)}

Globorotalia menardii var. multicamerata Cushman and Jarvis, 1930 J. Paleontol., v. 4 , p. 367 , pl. 34 , fig. 8

Globorotalia (Globorotalia) multicamerata Cushman and Jarvis. Blow, 1969, Intern. Conf. Plankt. Microfoss., Proc., v. 1, p. 367, pl. 7, fig. $7-9$; pl. 42 , fig. 7

This species is rare in Leg 37 samples. With the exception of its occurrence in one sample of late Miocene age, its distribution is limited to samples of Pliocene age. Forms referable to this species grade into $G$. cultrata (or $G$. cultrata limbata), and it is often difficult to distinguish between the taxa.

\section{Globorotalia petaliformis Boltovskoy}

(Plate 6, Figures 9-16)

Globorotalia petaliformis Boltovskoy, 1974, Initial Reports of the Deep Sea Drilling Project, v. 26, p. 707, pl. 14, fig. 1-16.

Typical specimens of $G$. petaliformis occur in upper Miocene sediments of Site 334. The species is best represented in Zone N17, although scattered rare specimens occur in Zones N16 and N15.

Specimens from Site 334 are variable, especially with regard to degree of biconvexity and degree of development of steplike structures between the chambers on the dorsal side of the test. Most specimens are unequally biconvex, having a more convex umbilical side. A few specimens are planoconvex. The steplike structures between the chambers vary in degree of development from complete absence to presence on the last several chambers. Boltovskoy (1974) also found a large amount of morphological variation in his specimens from the Indian Ocean.

\section{Globorotalia scitula (Brady)}

(Plate 6, Figures 17-19)

Pulvinulina scitula Brady, 1882, Roy. Soc. Edinburgh, Proc., v. 11 (1880-1882), no. 111 , p. 716 .

Globorotalia scitula (Brady). Parker, 1967, Am. Paleontol. Bull., v. 52 , p. 181 , pl. 27 , fig. 7 .

This species is present in nearly every Leg 37 sample. It is common in most Pliocene and Pleistocene samples, especially in the smaller fractions.

\section{Globorotalia siakensis (LeRoy)}

(Plate 6, Figure 20)

Globigerina siakensis LeRoy, 1939, Natuurk. Tjdschr. Nederl.-Indie, v. 99 , no. 6 , p. $39-40$, pl. 3 , fig. 30,31 .

Globorotalia (Turborotalia) siakensis (LeRoy). Blow, 1969, Intern Conf. Plankt. Microfoss., Proc., v. 1, p. 356, pl. 10, fig. 7-9; pl. 34 , fig. 4,5 ? 
Rare specimens of this species are present in Miocene sediment recovered immediately above basement at Site 335 .

Rare globorotalids which resemble $G$. siakensis were found in Zone N16 at Site 334 (see Plate 6, Figure 20). A typical specimen has an open, deep umbilicus and characteristics of the aperture which are similar to those of $G$. siakensis. However, the dorsal side of the test is slightly convex, and the final chamber is approximately the same size as the penultimate chamber. These characteristics are commonly associated with Globorotalia acostaensis and Globorotalia humerosa, and it is possible that the specimens belong to one of these species.

\section{Globorotalia sp. ef. G. subscitula Conato}

(Plate 7, Figures 1-4)

cf. Globorotalia scitula (Brady) var. subscitula Conato, 1964, Geol. Romana, v. 3, p. 209, pl. 2, fig. 16a-c.

cf. Globorotalia (Turborotalia) subscitula Conato. Blow, 1969, Intern.

Conf. Plankt. Microfoss., Proc., v. 1, p. 357, pl. 3, fig. 1-3; pl. 39 , fig. 8 .

Specimens which agree well with Blow's (1969) illustrations of $G$. subscitula are present in many samples of late Miocene age. The species is poorly represented at Site 335 , but occurs frequently in many samples from Site 334 . At the latter site it is especially frequent in Cores 2 through 5. The Leg 37 specimens do not appear to have peripheries which are as lobulate as the holotype illustrated by Conato (1964), but most other aspects of test morphology agree with the type description.

\section{Globorotalia tosaensis Takayanagi and Saito (Plate 7, Figures 5-7)}

Globorotalia tosaensis Takayanagi and Saito, 1962, Sci. Rept. Tohoku Univ., ser. 2 (Geol.), spec. vol. p. 81, pl. 28, fig. 11, 12.

Globorotalia tosaensis Takayanagi and Saito. Parker, 1967, Paleontol. Bull, v. 52, p. 181 , pl. 30, fig. 4-7.

This species occurs rarely in a few Pliocene samples.

\section{Globorotalia truncatulinoides (d'Orbigny)}

(Plate 7, Figure 8)

Rotalina truncatulinoides d'Orbigny, 1839, in Barker-Webb and Berthelot, Hist. Nat. Iles Canaries, "Foraminiferes,"v. 2, p. 132, pl. 2, fig. 25-27.

Globorotalia truncatulinoides (d'Orbigny). Parker, 1967, Am. Paleontol. Bull., v. 52, p. 181, pl. 31, fig. 1.

This species is common in samples of Pleistocene age. Occasional specimens are present in pre-Pleistocene samples as a result of drilling contamination.

\section{Globorotalia tumida (Brady)}

(Plate 7, Figures 9, 10)

Pulvimulina menardii (d'Orbigny) var. tumida Brady, 1877, Geol. Mag., new ser., v. 4, p. 535.

Globorotalia tumida (Brady). Parker, 1967, Am. Paleontol. Bull., v. 52 , pl. 32 , fig. 5-7.

Rare specimens of G. tumida are present in some samples of Pleistocene age. A single specimen from the Pliocene was found at Site 335 .

Globorotalia sp.

(Plate 7, Figures 11-15)

This species is common in the smaller-size fractions of several samples from Cores 12, 13, and 14 of Site 334. It is also present, but less common, in Core 20 of Site 334 and Core 5 of Site 335. All occurrences are confined to Zones N14, N15, and the lowermost part of Zone N16. The specimens exhibit some morphological variation, but all are small (maximum diameter of 100 to $300 \mu \mathrm{m}$ ), unkeeled, smooth-walled, and have six to six and one-half chambers in the final whorl. The aperture is umbilical-extraumbilical and bears a distinct lip.

\section{Genus HASTIGERINA Thompson, 1876}

\section{Hastigerina pelagica (d'Orbigny)}

(Plate 7, Figure 16)

Nonionina pelagica d'Orbigny, 1839, Voy. Am. Merid., "Foraminiferes," v. 5, p. 27, pl. 3, fig. 13, 14.
Hastigerina pelagica (d’Orbigny). Parker, 1967, Am. Paleontol. Bull., v. 52 , p. 159 , pl. 22 , fig. 6 .

Rare fragments of $H$. pelagica were found in a few samples from the upper Miocene, Pliocene, and Pleistocene. Only one sample, 334$1-2,50-52 \mathrm{~cm}$, contains more than a single fragment.

\section{Genus ORBULINA d'Orbigny, 1839}

\section{Orbulina suturalis Brönnimann}

Orbulina suturalis Bronnimann, 1951, Contrib. Cushman Found. Foram. Res., v. 2, p. 135, text-fig. 2, no. 1, 2, 5-8, 10; text-fig. 3, no. $3-8,11,13-16,18,20-22$; text-fig. 4 , no. $2-4,7-12,15,16,19$ 22.

Orbulina suturalis Brönnimann. Boltovskoy, 1974, Initial Reports of the Deep Sea Drilling Project, v. 26, p. 708, pl. 13, fig. 8.

This species is present in all samples of Miocene age, but is frequent only in samples from the lower cores near basement at Sites 334 and 335 . It occurs rarely in a few Pliocene samples and is absent in those of Pleistocene age.

\section{Orbulina universa d'Orbigny}

Orbulina universa d'Orbigny, 1839, in de la Sagra, Hist. Phys. Pol. Nat. Cuba, "Foraminiferes," p. 3, pl. 1, fig. 1.

Orbulina universa d'Orbigny. Krasheninnikov and Hoskins, 1973, Initial Reports of the Deep Sea Drilling Project, v. 20, p. 127, pl. 31 , fig. 11 .

Specimens were found in nearly all Leg 37 samples. Forms sometimes referred to the species Orbulina bilobata are present throughout the sediments at all sites.

\section{Genus PULLENIATINA Cushman, 1927}

Pulleniatina obliquiloculata (Parker and Jones) (Plate 7, Figures 17-20)

Pullenia obliquiloculata Parker and Jones, 1862, in Carpenter, Introduction to the study of foraminifera, p. 183.

Pulleniatina obliquiloculata obliquiloculata (Parker and Jones). Banner and Blow, 1967, Micropaleontology, v. 13, p. 137, pl. 3, fig. 4 ; pl. 4 , fig. 9.

Pulleniatina obliquiloculata finalis Banner and Blow, 1967, Micropaleontology, v. 13, p. 140, pl. 2, fig. 4-10; pl. 3, fig. 5a, b; pl. 4, fig. 10 .

Pulleniatina obliquiloculata (Parker and Jones). Parker, 1967, Am. Paleontol. Bull., v. 52, p. 172 , pl. 28, fig. 1.

This species is present in several Pleistocene samples, but is usually rare. It also occurs in sediments of late Pliocene age at Site 335.

\section{Pulleniatina primalis Banner and Blow}

(Plate 8, Figures 1-3)

Pulleniatina primalis Banner and Blow, 1967, Micropaleontology, v. 13 , p. 142 , pl. 1 , fig. $3-8$; pl. 3 , fig. 2 .

Pulleniatina primalis Banner and Blow. Parker, 1967, Am. Paleontol. Bull., v. 52, p. 173, pl. 27, fig. 5, 6 .

This species occurs rarely in the Pliocene of Site 335.

\section{Genus SPHAEROIDINELLA Cushman, 1927}

\section{Sphaeroidinella dehiscens (Parker and Jones) (Plate 8, Figure 4)}

Sphaeroidina bulloides d'Orbigny var. dehiscens Parker and Jones, 1865, Roy. Soc. London, Phil. Trans., v. 155, p. 369, pl. 19, fig. 5 .

Sphaeroidinella dehiscens (Parker and Jones). Parker, 1967, Am. Paleontol., v. 52, p. 161 , pl. 23, fig. 8,9 .

This species is found infrequently in several late Pliocene and Pleistocene samples.

\section{Sphaeroidinella seminulina (Schwager) (Plate 8, Figures 5-10)}

Globigerina seminulina Schwager, 1866, Novara exped. 1857-1859, Geol. Theil., Band 2, Abth. 2, p. 256, pl. 7, fig. 112.

Sphaeroidinella seminulina (Schwager). Parker, 1967, Am. Paleontol. Bull., v. 52, p. 161 , pl. 23, fig. 1-5. 
Sphaeroidinellopsis semimulina kochi (Caudri). Blow, 1969, Intern. Conf. Plankt. Microfoss., v. 1, p. 337 , pl. 30 , fig. 8 .

Sphaeroidinellopsis seminulina seminulina (Schwager). Blow, 1969, Intern. Conf. Plankt. Microfoss., v. 1, p. 337, pl. 30, fig. 7. This species is present in nearly all samples from Zone N14 to Zone N20. In Leg 37 samples $S$. seminulina is variable in size, number of chambers, and presence of the external cortex. Forms assigned to $S$. kochi (or $S$. seminulina kochi) by some workers are found infrequently in some samples of Miocene age. These are larger than typical $S$. seminulina and have one or two more chambers in the final whorl. This variant is included with $S$. seminulina in this report. Specimens of $S$. seminulina from Pliocene samples usually have rough test walls which lack cortices. Blow (1969) states that the cortex is very liable to alteration and solution, and it is assumed that a specimen without a cortex has lost it by way of solution. Both corticated and decorticated specimens are common in samples of Miocene age.

\section{Sphaeroidinella subdehiscens Blow}

(Plate 8, Figures 11-13)

Sphaeroidinella dehiscens subdehiscens Blow, 1959, Am. Paleontol. Bull., v. 39, p. 195, pl. 12, fig. 71,72 .

Sphaeroidinella subdehiscens Blow. Parker, 1967, Am. Paleontol. Bull., v. 52, p. 162 , pl. 23, fig. 6,7 .

Sphaeroidinellopsis subdehiscens subdehiscens (Blow). Blow, 1969, Intern. Conf. Plankt. Microfoss., v. 1, p. 338, pl. 30, fig. 1-3, 6. This species ranges from Zone N14 through Zone N20 in Leg 37 samples. Like $S$. seminulina, specimens may occur with or without the external cortex.

\section{Genus TURBOROTALITA Blow and Banner, 1962}

\section{Turborotalita humilis (Brady)}

(Plate 8, Figures 14-16)

Truncatulina humilis Brady, 1884, Rept. Voy. Challenger, Zool., v. 9, p. 665 , pl. 94 , fig. 7.

Turborotalita humilis (Brady). Parker, 1967, Am. Paleontol. Bull., v. 52 , p. 146 , pl. 17 , fig. 10 .

The recorded stratigraphic range of this species is Zone N17 to Zone N23 (Parker, 1967). In Leg 37 samples, however, it is restricted to Zone N23. Within this zone it occurs in the small-size fractions of nearly all samples, although it is always uncommon.

\section{ACKNOWLEDGMENTS}

I wish to acknowledge the Deep Sea Drilling Project for the opportunity to participate in Leg 37 and for providing funds for laboratory materials.

William N. Orr, Department of Geology, University of Oregon, Eugene, is thanked for reviewing the manuscript and for offering valuable suggestions. James S. Harrington of the Deep Sea Drilling Project provided technical advice during the investigation.

I am especially indebted to the Geology Department, Dalhousie University, Halifax, for the use of their scanning electron microscope and for providing transportation to Halifax so that I could use the SEM.

\section{REFERENCES}

Banner, F.T. and Blow, W.H., 1965. Progress in the planktonic foraminiferal biostratigraphy of the Neogene: Nature, v. 208, p. 1164.

Berggren, W.A., 1972. A Cenozoic time-scale-some implications for regional geology and paleobiogeography: Lethaia, v. 5, p. 195.

1973. The Pliocene time-scale: calibration of planktonic foraminiferal and calcareous nannoplankton zones: Nature, v. 243 , p. 391.

Berggren, W.A. and Amdurer, M., 1973. Late Paleogene (Oligocene) and Neogene planktonic foraminifera biostratigraphy of the Atlantic Ocean (Lat. $30^{\circ} \mathrm{N}$ to Lat. $30^{\circ} \mathrm{S}$ ): Riv. Ital. Paleontol., v. 79, p. 337.

Berggren, W.A. and van Couvering, J.A., 1974. The late Neogene: biostratigraphy, geochronology and paleoclimatology of the last 15 million years in marine and continental sequences: Amsterdam (Elsevier).

Blow, W.H., 1969. Late Middle Eocene to Recent planktonic foraminiferal biostratigraphy: Intern. Conf. Plank. Microfoss., 1st Proc., v. 1, Leiden (E.J. Brill), p. 199.

Boltovskoy, E., 1974. Neogene planktonic foraminifera of the Indian Ocean (DSDP, Leg 26). In Davies, T.A., Luyendyk, B.P., et al., Initial Reports of the Deep Sea Drilling Project, Volume 26: Washington (U.S. Government Printing Office), p. 675

Conato, V., 1964 Alcuni foraminiferi nuovi del Pliocene nordappenninico. Contributo 1: Geol. Romana, v. 3, p. 290.

Ellis, B.F. and Messina, A.R., 1940 et seq. Catalogue of foraminifera: Am. Mus. Nat. Hist. Spec. Publ.

Jenkins, D.G. and Orr, W.N., 1972. Planktonic foraminiferal biostratigraphy of the eastern Equatorial Pacific-DSDP Leg 9. In Hays, J.D., et al., Initial Reports of the Deep Sea Drilling Project, Volume 9: Washington, (U.S. Government Printing Office), p. 1059.

Parker, F.L., 1967. Late Tertiary biostratigraphy (planktonic foraminifera) of tropical Indo-Pacific deep-sea cores: Am. Paleontol. Bull., v. 52, p. 115.

Poag, C.W., 1972. Neogene planktonic foraminiferal biostratigraphy of the western North Atlantic: DSDP Leg 11. In Hollister, C.D., Ewing, J.I., et al., Initial Reports of the Deep Sea Drilling Project, Volume 11: Washington (U.S. Government Printing Office), p. 483.

Riedel, W.R. and Sanfilippo, A., 1971. Cenozoic Radiolaria from the western tropical Pacific, Leg 7. In Winterer, E.L., Riedel, W.R., et al., Initial Reports of the Deep Sea Drilling Project, Volume 7: Washington (U.S. Government Printing Office), p. 1529.

Smith, L.A., and Beard, J.H., 1973. The late Neogene of the Gulf of Mexico. In Worzel, J.L., Bryant, W., et al., Initial Reports of the Deep Sea Drilling Project, Volume 10: Washington (U.S. Government Printing Office), p. 643. 


\section{PLATE 1}

Figure $1 \quad$ Candeina nitida d'Orbigny.

Sample 334-12-4, 126-128 cm, late Miocene, $\times 86$.

Figure 2 Globigerina apertura Cushman.

Sample 332A-5-6, 125-127 cm, late Pliocene, $\times 95$.

Figures 3-5 Globigerina atlantica Berggren.

3, 5. Sample $335-4-1,130-132 \mathrm{~cm}$, late Miocene, $\times 91$.

4. Sample $335-4-3,51-53 \mathrm{~cm}$, late Miocene, $\times 74$.

Figures 6-8 Globigerina bulloides d'Orbigny.

6. Sample 334-1-1, 30-32 cm, Pleistocene, $\times 79$.

7. Sample $332 \mathrm{~A}-5-4,125-127 \mathrm{~cm}$, late Pliocene, $\times 45$. A large Pliocene form.

8. Sample 334-13-6, 126-128, late Miocene, $\times 56$.

A late Miocene variant.

Figure 9 Globigerina calida Parker.

Sample 334-1-2, 50-52 cm, Pleistocene, $\times 54$.

Figure 10 Globigerina decoraperta Takayanagi and Saito.

Sample 334-12-4, 126-128 cm, late Miocene, $\times 142$.

Figures 11-13 Globigerina digitata Brady.

11. Sample 334-1-2, 50-52 cm, Pleistocene, $\times 80$.

12. Sample 333-1-2, $125-127 \mathrm{~cm}$, Pleistocene, $\times 65$.

13. Sample 333-1-2, $125-127 \mathrm{~cm}$, Pleistocene, $\times 64$.

Figure $14 \quad$ Globigerina falconensis Blow.

Sample 332A-2-2, 125-127 cm, late Pliocene, $\times 94$.

Figures 15, 16 Globigerina nepenthes Todd.

Sample 334-8-2, 125-127 cm, late Miocene.

15. $\times 84$.

16. $\times 73$.

Figures 17-19 Globigerina pachyderma (Ehrenberg).

Sample 334-1-2, 50-52 cm, Pleistocene.

17. $\times 96$.

18. $\times 102$.

19. $\times 116$. 
PLATE 1
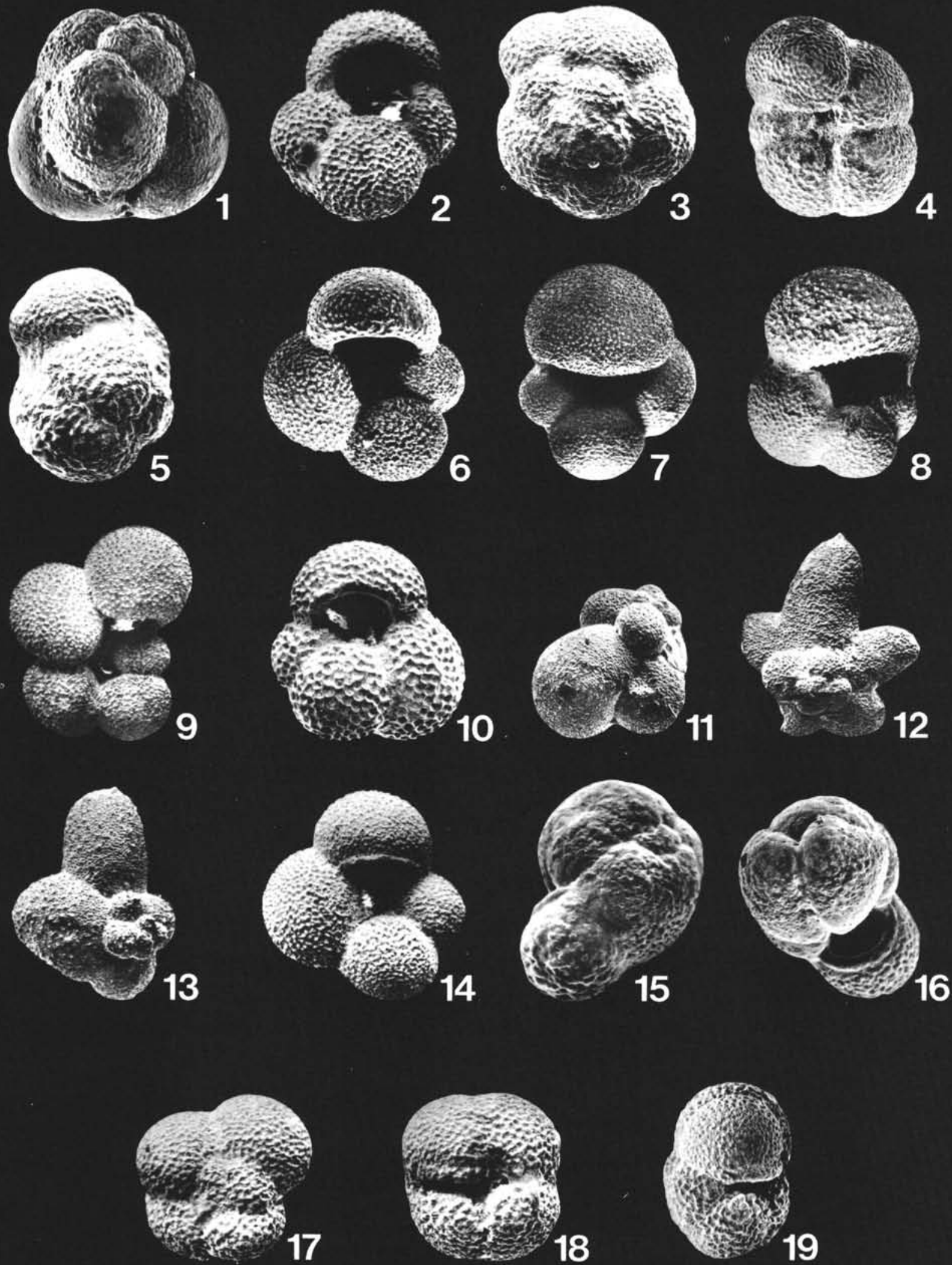


\section{PLATE 2}

Figures 1,2 Globigerina praedigitata Parker.

1. Sample 334-6, CC, late Miocene, $\times 85$.

2. Sample $332 \mathrm{~A}-5-4,125-127 \mathrm{~cm}$, late Pliocene, $\times 90$.

Figures 3-6 Globigerina quinqueloba Natland.

3. Sample 334-1-2, 50-52 cm, Pleistocene, $\times 146$.

4. Sample 334-1-2, 50-52 cm, Pleistocene, $\times 165$.

5. Sample 334-7-1, 50-52 cm, late Miocene, $\times 164$. Small form.

6. Sample 334-7-1, 50-52 cm, late Miocene, $\times 174$.

Small form.

Figure 7 Globigerina rubescens Hofker.

Sample 333-1-2, 50-52 cm, Pleistocene, $\times 175$.

Figures 8-10 Globigerinella aequilateralis Brady.

Sample 334-1-1, 30-32 cm, Pleistocene.

8. $\times 60$.

9. $\times 60$.

10. $\times 57$.

Figures 11-13 Globigerinita glutinata (Egger).

Sample 332A-2-3, 50-52 cm, late Pliocene.

11. $\times 144$.

12. $\times 136$. Umbilical view of specimen without a bulla.

13. $\times 140$. Umbilical view of specimen with a bulla.

Figure $14 \quad$ Globigerinita uvula (Ehrenberg).

Sample 334-7-1, 50-52 cm, late Miocene, $\times 233$.

Figure $15 \quad$ Globigerinoides conglobatus (Brady).

Sample 334-1-2, 50-52 cm, Pleistocene, $\times 55$.

Figures 16,17 Globigerinoides extremus Bolli and Bermudez. Sample 334-2-1, 50-52 cm, late Miocene.

16. $\times 81$.

17. $\times 72$. 
PLATE 2
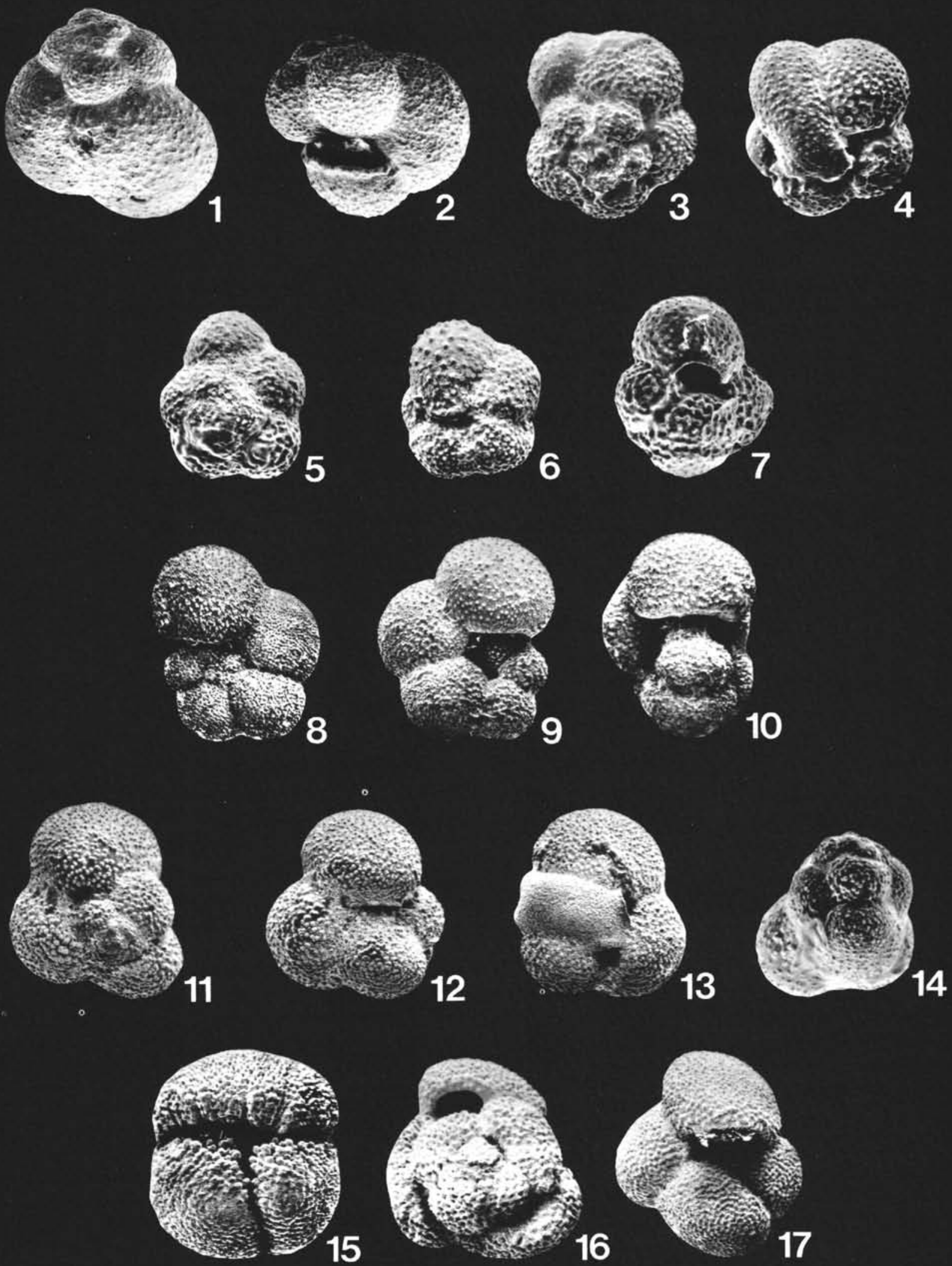


\section{PLATE 3}

Figures 1-3 Globigerinoides mitra Todd var. A.

1. Sample 334-7-6, 125-127 cm, late Miocene, $\times 68$.

2. Sample 334-2-6, 50-52 cm, late Miocene, $\times 55$.

3. Sample $334-7-5,125-127 \mathrm{~cm}$, late Miocene, $\times 62$.

Figures 4, $5 \quad$ Globigerinoides mitra Todd var. B.

Sample 334-9, CC, late Miocene.

4. $\times 80$.

5. $\times 66$.

Figure $6 \quad$ Globigerinoides obliquus Bolli.

Sample 335-1-3, 125-127 cm, late Pliocene, $\times 99$.

Figures 7, 8 Globigerinoides ruber (d'Orbigny).

Sample 334-1-1, 30-32 cm, Pleistocene.

7. $\times 84$.

8. $\times 96$.

Figures 9-11 Globigerinoides sacculifer (Brady).

9. Sample 334-7-1, 50-52 cm, late Miocene, $\times 68$.

10. Sample 334-7-1, 50-52 cm, late Miocene, $\times 70$.

11. Sample 332A-5-6, 125-127 cm, late Pliocene, $\times 97$.

Specimen without a saccate final chamber.

Figure 12 Globoquadrina advena Bermudez.

Sample 335-5-1, 125-127 cm, middle Miocene, $\times 62$.

Figures 13-15 Globoquadrina altispira (Cushman and Jarvis).

Sample 334-7-2, 130-132 cm, late Miocene.

13. $\times 85$.

14. $\times 83$.

15. $\times 77$.

Figures 16-19 Globoquadrina dehiscens (Chapman, Parr, and Collins).

16. Sample $334-13-5,126-128 \mathrm{~cm}$, late Miocene, $\times 67$.

17. Sample $334-13-5,126-128 \mathrm{~cm}$, late Miocene, $\times 62$.

18. Sample $334-12-4,126-128 \mathrm{~cm}$, late Miocene, $\times 86$.

19. Sample $335-5-1,148-150 \mathrm{~cm}$, middle Miocene, $\times 76$.

Specimen showing bullalike structure covering umbilicus. 

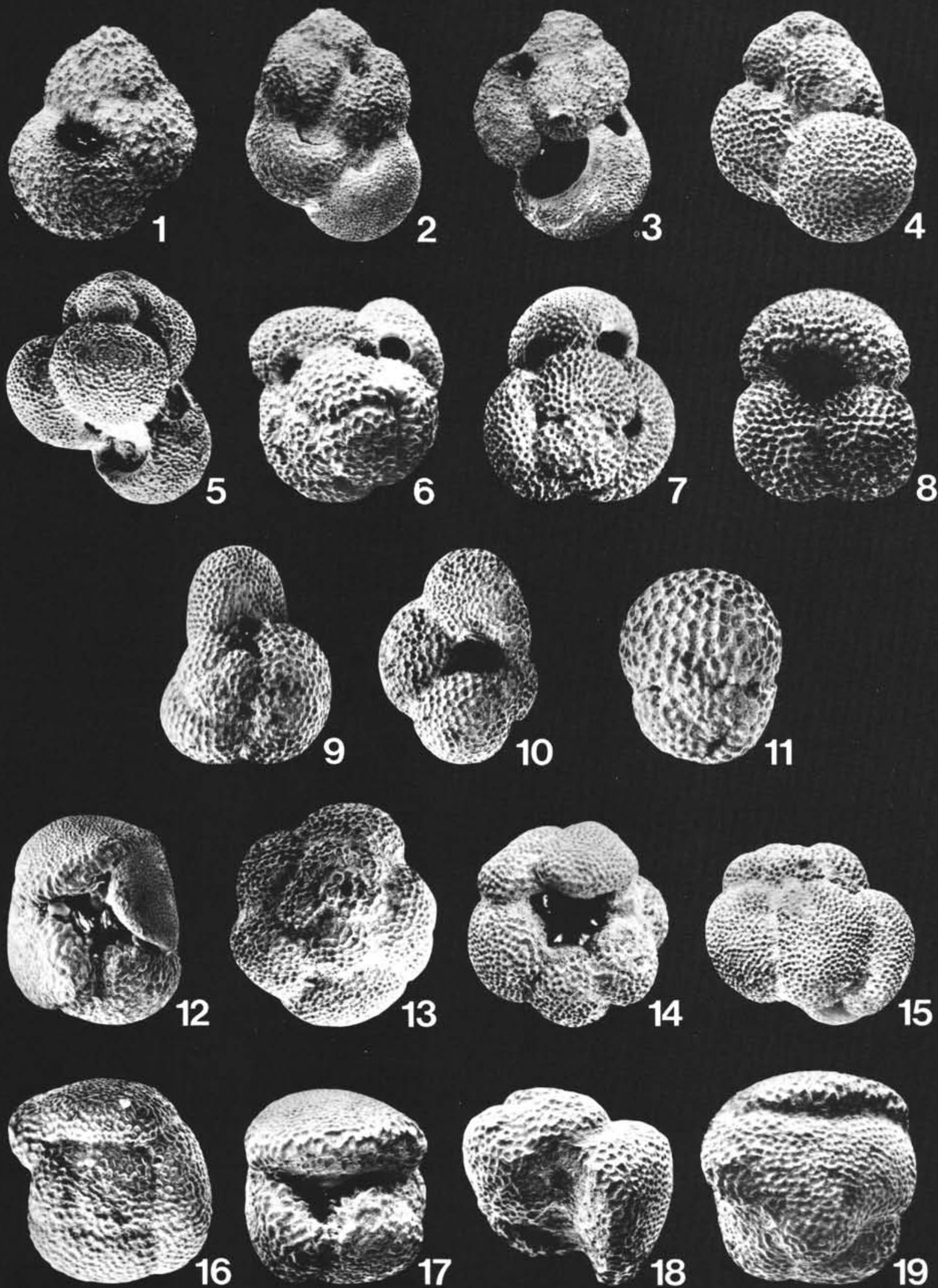


\section{PLATE 4}

Figures 1-3 Globoquadrina dutertrei (d'Orbigny).

Sample 332A-1-1, 110-112 cm, Pleistocene.

1. $\times 69$.

2. $\times 75$.

3. $\times 63$.

Figures 4-6 Globoquadrina venezuelana (Hedberg).

Sample 334-6, CC, late Miocene.

4. $\times 80$.

5. $\times 81$.

6. $\times 92$. Specimen with diminutive final chamber.

Figure $7 \quad$ Globorotalia acostaensis Blow.

Sample 333-2-1, 125-127 cm, late Pliocene, $\times 120$.

Figures 8-10 Globorotalia cibaoensis Bermudez.

8. Sample $335-3$, CC, early Pliocene, $\times 75$.

9. Sample 334-3-2, 50-52 cm, late Miocene, $\times 74$.

10. Sample 334-2, CC, late Miocene, $\times 59$.

Figures 11-13 Globorotalia continuosa Blow.

11. Sample 334-11-4, 124-126 cm, late Miocene, $\times 120$.

12. Sample $334-11-4,124-126 \mathrm{~cm}$, Late Miocene, $\times 113$.

13. Sample $335-5-1,125-127 \mathrm{~cm}$, Middle Miocene, $\times 157$.

Figures 14-16 Globorotalia crassaformis (Galloway and Wissler). Sample 333-2-1, 125-127 cm, late Pliocene.

14. $\times 77$.

15. $\times 70$

16. $\times 74$

Figures 17-19 Globorotalia crassula Cushman and Stewart.

17. Sample 332B-1-1, $46-48 \mathrm{~cm}$, late Pliocene, $\times 67$.

18. Sample $333-4-2,125-127 \mathrm{~cm}$, late Pliocene, $\times 62$.

19. Sample $333-4-2,125-127 \mathrm{~cm}$, late Pliocene, $\times 60$. 
PLATE 4
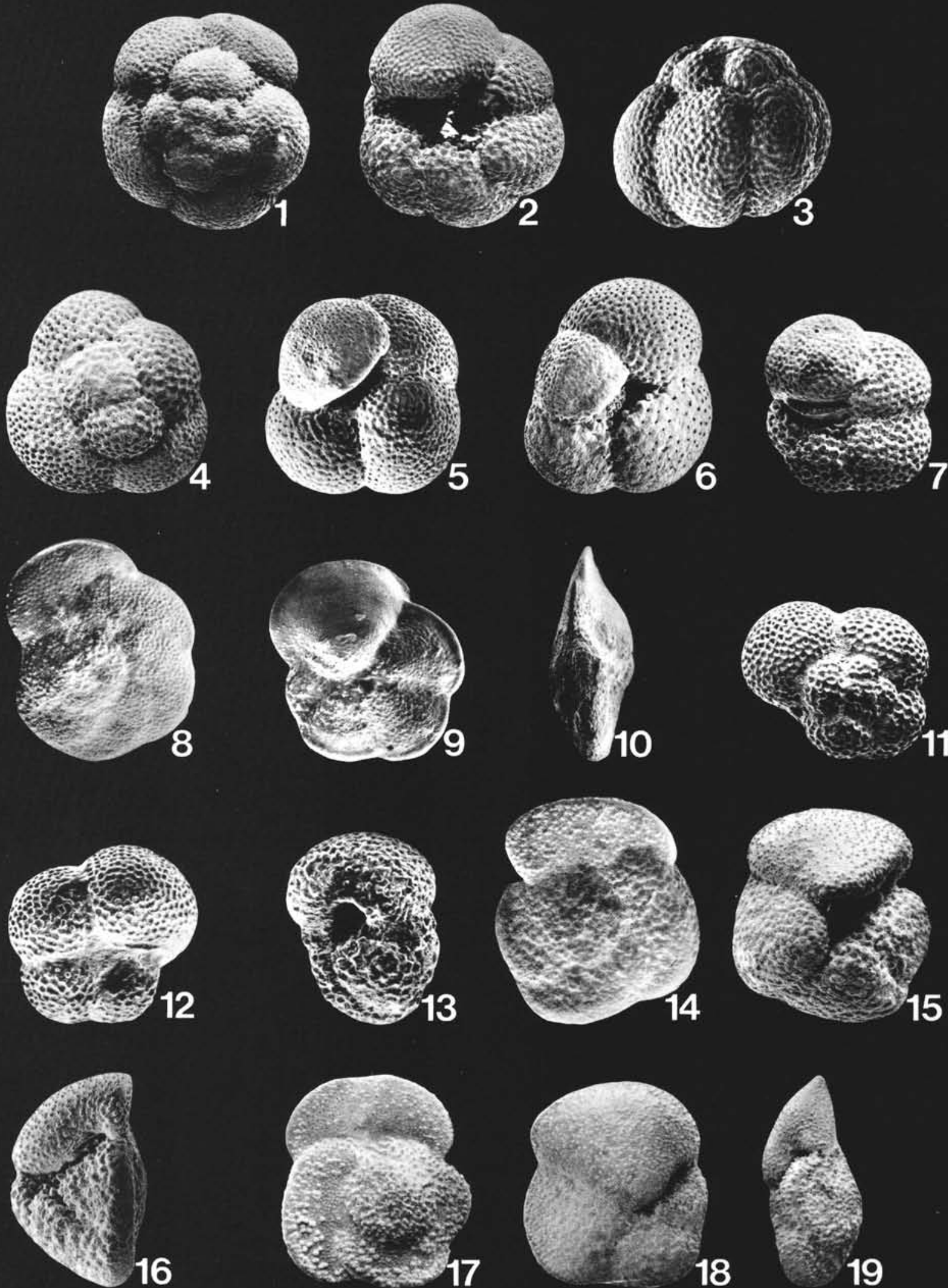


\section{PLATE 5}

Figures 1-3 Globorotalia cultrata (d'Orbigny).

1. $334-13-2,51-53 \mathrm{~cm}$, late Miocene, $\times 43$.

2. $334-13-5,126-128 \mathrm{~cm}$, late Miocene, $\times 47$.

3. $334-13-5,126-128 \mathrm{~cm}$, late Miocene, $\times 47$.

Figures 4, $5 \quad$ Globorotalia exilis Blow.

4. Sample $333-4-3,125-127 \mathrm{~cm}$, late Pliocene, $\times 56$.

5. Sample 333-4-3, 50-52 cm, late Pliocene, $\times 62$.

Figures 6-8 Globorotalia hirsuta (d'Orbigny).

Sample 334-1-2, 50-52 cm, Pleistocene.
6. $\times 46$.
7. $\times 48$.
8. $\times 46$.

Figures 9-11 Globorotalia inflata (d'Orbigny).

Sample 334-1-1, 30-32 cm, Pleistocene.

9. $\times 74$.

10. $\times 69$.

11. $\times 77$

Figures 12-15 ?Globorotalia inflata (d'Orbigny).

12. Sample 332B-1-4, 125-127 cm, late Pliocene, $\times 84$.

13. Sample 332B-1-5, $43-45 \mathrm{~cm}$, late Pliocene, $\times 77$.

14. Sample 332B-1-1, 125-127 cm, late Pliocene, $\times 84$.

15. Sample 332A-5-2, $125-127 \mathrm{~cm}$, late Pliocene, $\times 69$.

Figures 16-18 Globorotalia margaritae Bolli and Bermudez.

Sample 335-2, CC, early Pliocene.

16. $\times 63$.

17. $\times 66$.

18. $\times 64$. 

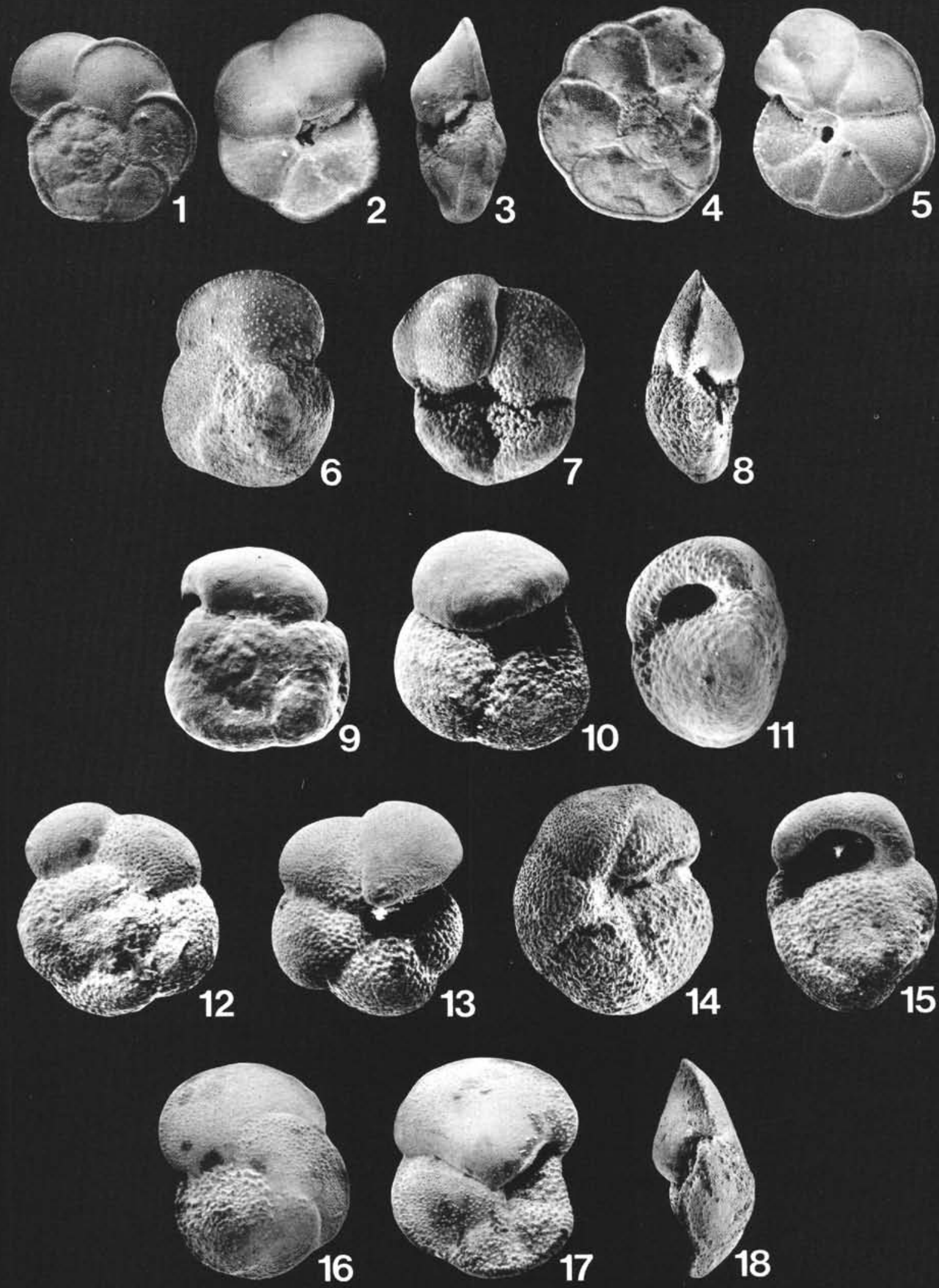


\section{PLATE 6}

Figures 1-3 Globorotalia miocenica Palmer.

Sample 335-1-4, 125-127 cm, late Pliocene.

1. $\times 63$.

2. $\times 72$.

3. $\times 72$.

Figures 4, $5 \quad$ Globorotalia miozea conoidea Walters.

4. Sample $334-5-2,18-20 \mathrm{~cm}$, late Miocene, $\times 57$.

5. Sample 334-5-1, 99-101 cm, late Miocene, $\times 55$.

Figures 6-8 Globorotalia multicamerata Cushman and Jarvis.

6. Sample 335-2, CC, early Pliocene, $\times 49$.

7. Sample $332 \mathrm{~A}-5-2,51-52 \mathrm{~cm}$, late Pliocene, $\times 67$.

8. Sample $335-3-1,50-52 \mathrm{~cm}$, early Pliocene, $\times 62$.

Figures 9-16 Globorotalia petaliformis Boltovskoy.

9. Sample $334-5-1,99-101 \mathrm{~cm}$, late Miocene, $\times 64$.

10. Sample $334-5-1,99-101 \mathrm{~cm}$, late Miocene, $\times 51$.

11. Sample $334-5-1,99-101 \mathrm{~cm}$, late Miocene, $\times 60$.

12. Sample $334-5-1,99-101 \mathrm{~cm}$, late Miocene, $\times 74$.

13. Sample $334-5-12,18-20 \mathrm{~cm}$, late Miocene, $\times 78$.

14. Sample $334-10-2,108-110 \mathrm{~cm}$, late Miocene, $\times 60$.

15. Sample 334-5-1, 99-101 cm, late Miocene, $\times 51$.

16. Sample $334-5-1,99-101 \mathrm{~cm}$, late Miocene, $\times 95$.

Figures 17-19 Globorotalia scitula (Brady).

Sample 334-1-2, 50-52 cm, Pleistocene.

17. $\times 69$.

18. $\times 90$.

19. $\times 81$.

Figure 20 cf. Globorotalia siakensis (LeRoy).

Sample 334-11, CC, late Miocene, $\times 94$.

Also shows some characteristics of Globorotalia acostaensis and Globorotalia humerosa, and may be assignable to one of these species. 
PLATE 6
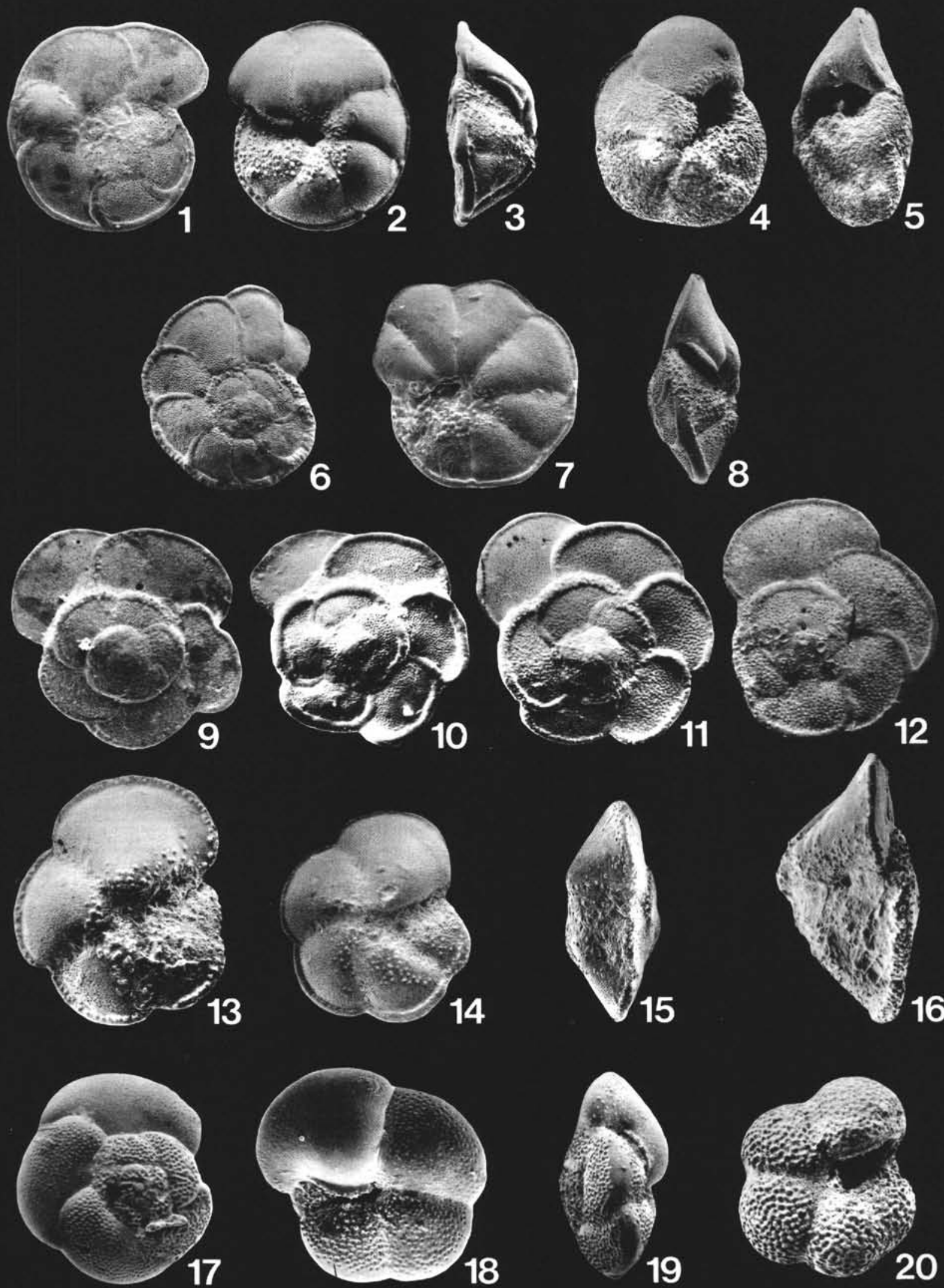


\section{PLATE 7}

Figures 1-4 Globorotalia sp. cf. G. subscitula Conato. Sample 334-2-3, 50-52 cm, late Miocene.
1. $\times 84$.
2. $\times 72$.
3. $\times 80$.
4. $\times 78$.

Figures 5-7 Globorotalia tosaensis Takayanagi and Saito. Sample 332A-5-2, 51-52 cm, late Pliocene.
5. $\times 91$.
6. $\times 72$.
7. $\times 99$.

Figure $8 \quad$ Globorotalia truncatulinoides (d'Orbigny).

Sample 334-1-2, 50-52 cm, Pleistocene, $\times 63$.

Figures 9,10 Globorotalia tumida (Brady).

9. Sample 332-1-2, 50-52 cm, Pleistocene, $\times 52$.

10. Sample 332-1-3, 135-137 cm, Pleistocene, $\times 65$.

Figures 11-15 Globorotalia sp.

Sample 334-13-5, 126-128 cm, late Miocene.
11. $\times 120$.
12. $\times 115$.
13. $\times 108$.
14. $\times 108$.
15. $\times 104$.

Figure $16 \quad$ Hastigerina pelagica (d'Orbigny).

Sample 334-1-2, 50-52 cm, Pleistocene, $\times 76$.

Figures 17-20 Pulleniatina obliquiloculata (Parker and Jones). 17. Sample 332A-1-1, 110-112 cm, Pleistocene, $\times 66$.

18. Sample 335-1-2, 50-52 cm, late Pliocene, $\times 81$. 19. Sample $335-1-2,50-52 \mathrm{~cm}$, late Pliocene, $\times 76$. 20. Sample $332 \mathrm{~A}-1-1,110-112 \mathrm{~cm}$, Pleistocene, $\times 53$. 


\section{PLATE 7}
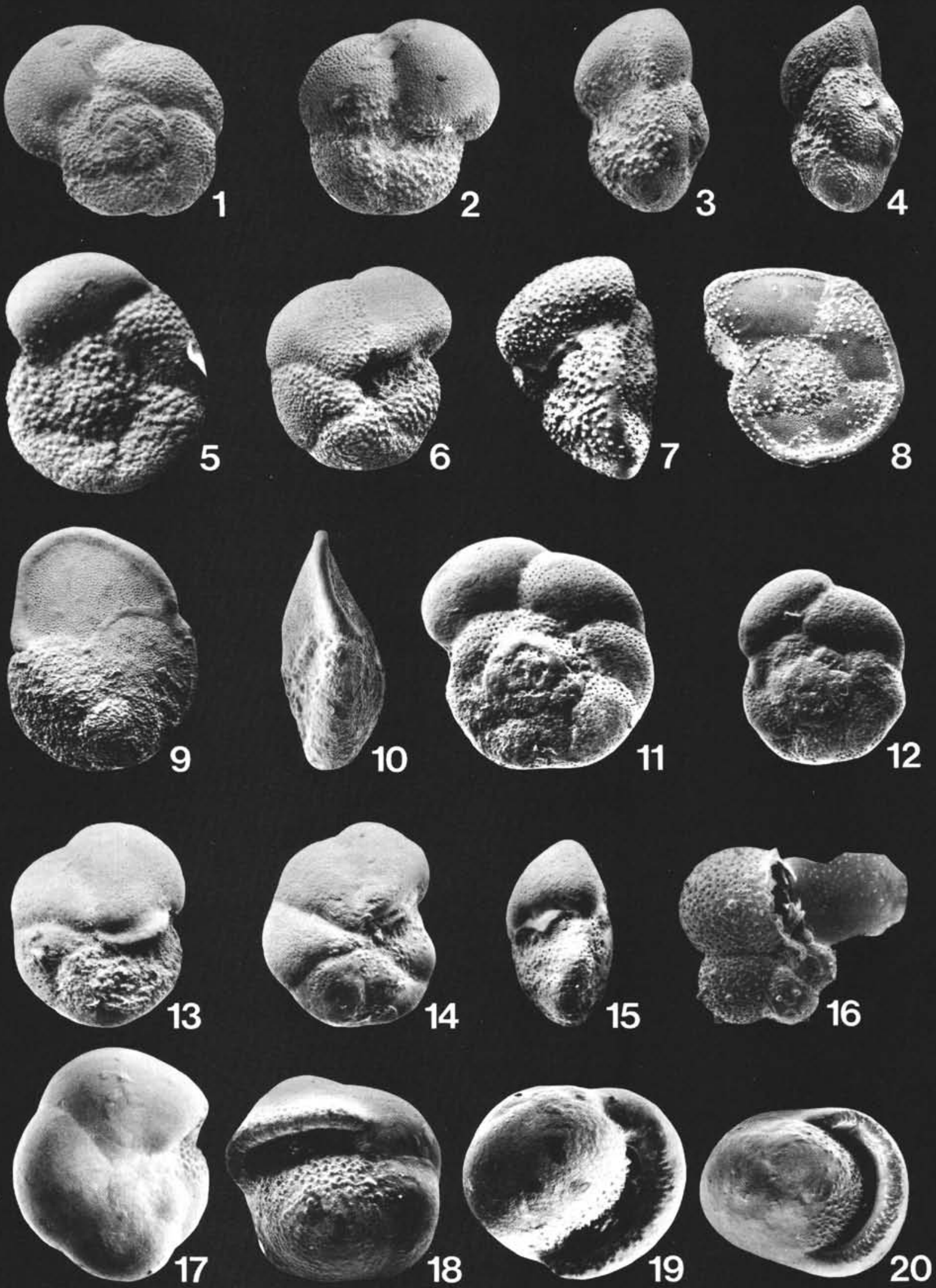


\section{PLATE 8}

Figures 1-3 Pulleniatina primalis Banner and Blow.

1. Sample $335-1-3,125-127 \mathrm{~cm}$, late Pliocene, $\times 90$.

2. Sample 335-1-2, 50-52 cm, late Pliocene, $\times 81$.

3. Sample $335-1-3,50-52 \mathrm{~cm}$, late Pliocene, $\times 59$.

Figure 4 Sphaeroidinella dehiscens (Parker and Jones).

Sample 332A-1-1, 110-112 cm, Pleistocene, $\times 53$.

Figures 5-10 Sphaeroidinella seminulina (Schwager).

5. Sample 334-3-2, 50-52 cm, late Miocene, $\times 65$.

6. Sample 334-3-2, 50-52 cm, late Miocene, $\times 66$.

7. Sample $335-3-1,50-52 \mathrm{~cm}$, early Pliocene, $\times 63$.

8. Sample $335-3-1,50-52 \mathrm{~cm}$, early Pliocene, $\times 60$.

9. Sample $334-7-6,125-127 \mathrm{~cm}$, late Miocene, $\times 41$.

10. Sample 334-7, CC, late Miocene, $\times 38$.

Figures 7-10 show decorticated specimens. Figures 9 and 10 are forms sometimes assigned to $S$. kochi or S. seminulina kochi.

Figures 11-13 Sphaeroidinella subdehiscens Blow.

11. Sample 334-7-1, 50-52 cm, late Miocene, $\times 84$.

12. Sample $335-3-1,50-52 \mathrm{~cm}$, early Pliocene, $\times 91$.

13. Sample $335-3-1,50-52 \mathrm{~cm}$, early Pliocene, $\times 76$.

Figures 12 and 13 show decorticated specimens.

Figures 14-16 Turborotalita humilis (Brady).

Sample 333-1-2, 50-52 cm, Pleistocene.

14. $\times 154$.

15. $\times 139$.

16. $\times 154$ 
PLATE 8

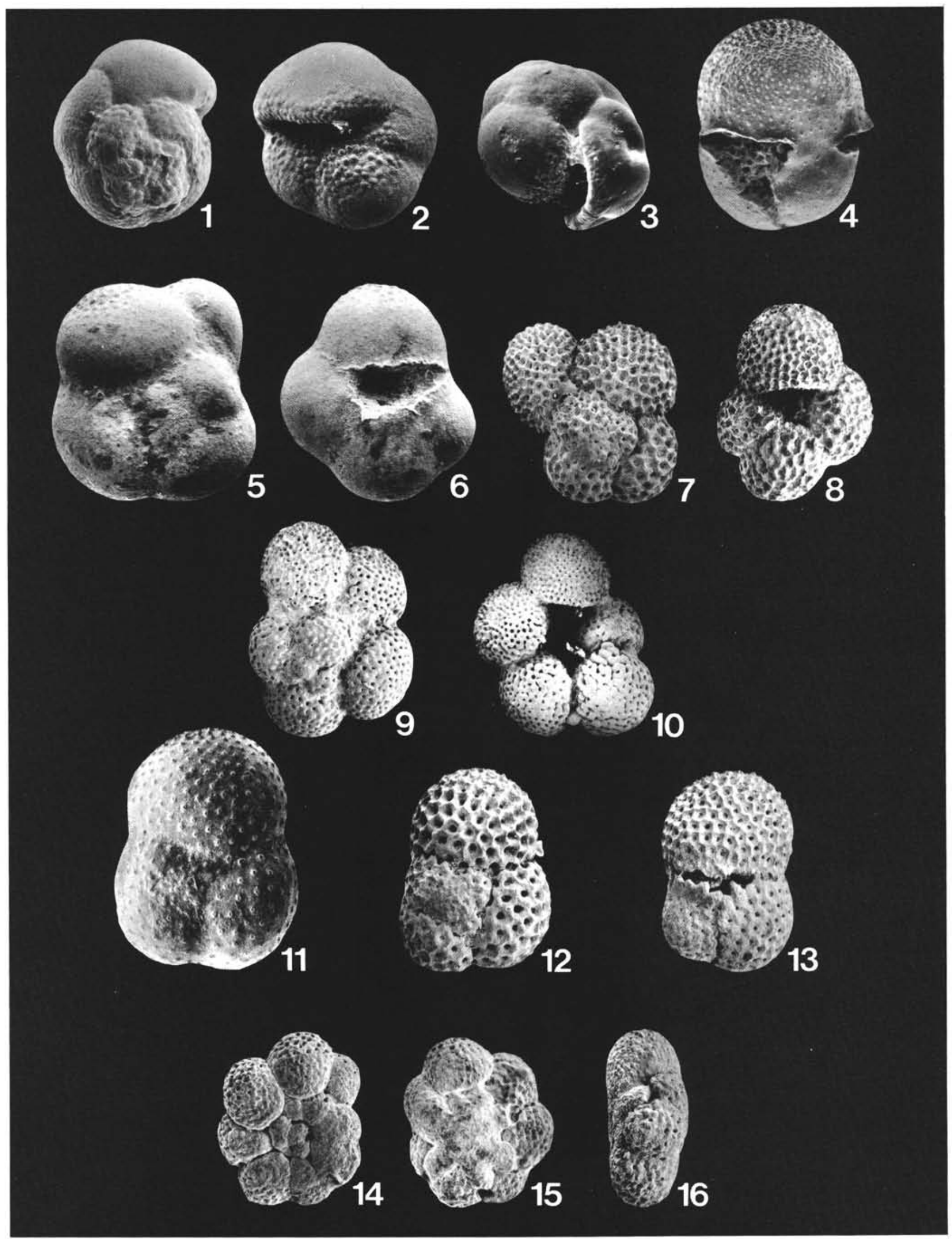

